\title{
On the investment value of sell-side analyst recommendation revisions in the UK
}

\author{
Chen Su${ }^{1}$ (D) $\cdot$ Hanxiong Zhang ${ }^{2} \cdot$ Kenbata Bangassa $^{3} \cdot$ Nathan Lael Joseph $^{4}$
}

Published online: 9 August 2018

(c) The Author(s) 2018

\begin{abstract}
This study conducts a comprehensive investigation into the investment value of sell-side analyst recommendation revisions in the UK, using a unique dataset from 1995 to 2013. Our rolling window analysis shows that, on average, upgrades fail to generate any significantly positive abnormal returns in any period of time, even before transaction costs. In addition, although downgrades could generate significantly negative abnormal gross returns over some periods of time, these observed significant returns disappear after accounting for transaction costs. Overall, our bootstrapping simulations confirm sell-side analysts' lack of skill in making valuable up/downward revisions to cover the size of transaction costs, irrespective of whether these revisions are made by high-ranking brokerage houses or not. However, an industry-based analysis shows that, within two high-tech industry sectors, i.e., Health Care and Technology sectors, sell-side analysts possess certain skill in making valuable downgrades over some periods of time and, in particular, such skill is sufficient to offset transaction costs.
\end{abstract}

Keywords Analyst recommendation revisions - Transaction costs · High-ranking brokerage houses $\cdot$ Industry $\cdot$ Bootstrapping simulations

JEL Classification G11 · G12 · G14 · G17 · G24

Chen Su

chen.su@ncl.ac.uk

Hanxiong Zhang

hzhang@lincoln.ac.uk

Kenbata Bangassa

kenbata@liv.ac.uk

Nathan Lael Joseph

n.1.joseph@aston.ac.uk

1 Newcastle University Business School, 5 Barrack Road, Newcastle upon Tyne NE1 4SE, UK

2 Lincoln International Business School, University of Lincoln, Brayford Pool, Lincoln LN6 7TS, UK

3 University of Liverpool Management School, Chatham Building, Liverpool L69 7ZH, UK

4 Aston Business School, Aston University, Aston Triangle, Birmingham B4 7ET, UK 


\section{Introduction}

Sell-side analysts working for brokerage houses play an important role in the capital markets by collecting and analyzing a variety of market, industry, and firm-specific information and then making stock recommendations. ${ }^{1}$ These stock recommendations, disseminated through electronic and print media, have been widely used by investors in their investment decisions. Whether sell-side analyst recommendations can truly create investment value and promote market efficiency has been of great interest to financial academics. The related literature can stretch as back as the pioneering study of Cowles (1933), which shows that investors are not able to add value to the market when they follow analyst recommendations. The inability of financial analysts to predict stock price movements is confirmed by numerous following studies (see, e.g., Colker 1963; Logue and Tuttle 1973; Groth et al. 1979; among others), in spite of a substantial amount of money spent by brokerage houses on security analysis (Grossman and Stiglitz 1980). ${ }^{2}$ In contrast, Stickel (1995) and Womack (1996) report that upgrades (downgrades) — favorable (unfavorable) changes in analyst recommendations - are accompanied by significantly positive (negative) returns at the time of their announcements. Barber et al. (2001) prove the existence of profitable investment strategies based on publicly available analyst recommendations, presenting a challenge to the semi-strong form of efficient market hypothesis (EMH). However, these investment strategies require a great deal of trading and generate considerable transaction costs, suggesting that the observed market inefficiencies are not easily exploitable by investors (see, also, Jegadeesh et al. 2004; Mikhail et al. 2004). Altinkiliç and Hansen (2009) further call into question the information role played by financial analysts in that their stock recommendation revisions often piggyback on public information (e.g., corporate events and news), thus providing investors with little incremental information (see, also, Altinkiliç et al. 2013).

Despite the existence of extensive sell-side analyst research in the US, empirical evidence on the investment value of analyst recommendations remains mixed. Jegadeesh and Kim (2006, p. 275) argue that an in-depth examination in other developed markets "will give us a more comprehensive picture of the extent to which the unique skill of analysts are useful for investors". The UK stock market, a highly developed and sophisticated market, provides us with an appropriate setting to shed additional light on the existing controversy within this area of research, while it has received very scant attention in the financial literature. For example, Dimson and Fraletti (1986) examine an unpublished sample of 1649 telephone recommendations made by a leading UK brokerage house in 1983, but they find no significant abnormal returns for the recommended stocks. Ryan and Taffler (2006, p. 372) argue that the study of Dimson and Fraletti (1986) examines stock recommendations made by "a single UK brokerage house only and is biased towards large capitalization stocks". Ryan and Taffler (2006) investigate a sample of 2506 changes in analyst recommendations

\footnotetext{
1 Sell-side analysts typically work for brokerage houses (or investment banks) and make stock recommendations to investors in the capital markets, while buy-side analysts usually work for pension fund or mutual fund firms and make stock recommendations to money managers of the fund that employs them. This study focuses on stock recommendation revisions, exclusively made by sell-side analysts working for brokerage houses in the UK.

${ }^{2}$ Grossman and Stiglitz (1980) argue that if prices fully reflect all available information, then the use of analyst recommendations cannot generate superior returns, and brokerage houses should not spend large sums of money on security analysis, nor should market participants have any incentive to pay for such costly information.
} 
made by six London-based brokerage houses from December 1993 to June 1995, showing that stock prices are significantly affected by analyst recommendation revisions.

Given the limited observations and short sample periods examined in prior UK studies, which generally suffer from small sample bias, this study aims to conduct a comprehensive investigation into a novel real-time database, uniquely created by Morningstar Company Intelligence. Our final sample consists of 70,220 analyst recommendation revisions for stocks either on the main market of the London Stock Exchange (LSE) or on the Alternative Investment Market (AIM) from January 1995 to June 2013; as such, our dataset is much larger than has been employed in prior UK studies. With the Morningstar database, we take an investor-oriented, calendar-time perspective, ${ }^{3}$ to assess the performance of investment strategies based on UK sell-side analyst recommendation revisions. Our study is close to Barber et al. (2001) and Barber et al. (2007), but differs from them in several major respects. For example, Barber et al. (2007) include initiations, resumptions, and reiterations when constructing their portfolios. However, sell-side analysts often leave their stock recommendations unchanged for long periods of time; as a result, these stock recommendations become stale and less informative over time (see, Jegadeesh et al. 2004; Boni and Womack 2006; Jegadeesh and Kim 2006, 2010). Therefore, unlike Barber et al. (2007), we construct two upgrade and downgrade portfolios by exclusively focusing on analyst recommendation revisions. Specifically, the upgrade portfolio includes all stocks with upward revisions to Strong Buys or Buys from previous Strong Sells, Sells, or Holds, while the downgrade portfolio includes all stocks with downward revisions to Strong Sells, Sells, or Holds from previous Strong Buys or Buys.

In addition, different from Barber et al. (2001) and Barber et al. (2007), we evaluate the performance of the upgrade and downgrade portfolios on a 1-year rolling window basis, using the intercepts derived from the single-factor capital asset pricing model (CAPM), the Fama and French (1993) three-factor model, the Carhart (1997) four-factor model, and the Fama and French (2015) five-factor model. The rolling window analysis, which has not been used in prior sell-side analyst research, to the best of our knowledge, enables us to more effectively capture the time-varying portfolio performance over the long sample period, while the use of various single- and multi-factor models helps rule out the concern on the poor model of asset pricing raised by Barber et al. (2001).

Our empirical investigation proceeds in three main parts, showing some interesting results that are robust to alternative model specifications. In the first part, we examine the time-varying daily abnormal returns (both gross and net of transaction costs) to the upgrade and downgrade portfolios using the whole sample of analyst recommendation revisions. Specifically, on average, the upgrade portfolio generates no significantly positive abnormal gross (or net) returns in any period of time, suggesting that upgrades are in general valueless. In contrast, the downgrade portfolio generates significantly negative abnormal gross returns in several periods of time. For example, the negative abnormal gross returns to the downgrade portfolio are statistically significant, at least at the $5 \%$ level, from April 2001 to January 2003, ranging from -3.50 basis points to -6.40 basis points, and from March 2009 to June 2010, ranging from -3.45 basis points to -8.59 basis points. However, given the existence of massive portfolio rebalancing, the downgrade portfolio

\footnotetext{
${ }^{3}$ Barber et al. (2001) point out that event-time analysis is a more analyst-oriented approach, which does not measure the profits to an implementable investment strategy (see, also, Stickel 1995; Womack 1996; Ivkovic and Jegadeesh 2004; Green 2006; Brown et al. 2009).
} 
does not generate significant abnormal net returns after taking a reasonable level of transaction costs into account.

Although a large number of investment strategies based on analyst recommendation revisions fail to make profits after transaction costs, Barber et al. (2001, p. 537) argue that "it remains an open question whether other types of trading strategies could be profitable". Inspired by Barber et al. (2001), we further employ two alternative investment strategies to assess: (1) whether analyst recommendation revisions made by high-ranking brokerage houses are more valuable in the UK; and (2) whether UK analyst recommendation revisions within specific industry sectors can make large enough profits to offset transaction costs.

On the one hand, it has been well reported that brokerage houses and their analysts, as repetitive players in the capital markets, obtain and accumulate their reputation capital, which is directly affected by the performance of stocks they recommend (see, Womack 1996; Brown et al. 2009). Therefore, it is possible that the superior performance made by some star sell-side analysts (e.g., those working for high-ranking brokerage houses) is balanced by the inferior performance made by their non-star counterparts (Fama and French 2010). In the second part of our empirical investigation, we replicate all analyses in the first part using a subsample of 11,016 analyst recommendation revisions exclusively made by the top 5 brokerage houses, measured by their positions on the annual All-Europe Research Team published by Institutional Investor (see "Appendix 1"). The subsample results, however, are qualitatively the same as those using the whole sample, suggesting that reputation of brokerage houses does not play a significant role in enhancing the investment value of sell-side analyst recommendation revisions in the UK.

On the other hand, prior sell-side analyst research controls for a wide range of stock characteristics (see, e.g., Stickel 1995; Womack 1996; Jegadeesh et al. 2004; Anderson et al. 2017), other than for industry factor. Jegadeesh et al. (2004, p. 1118) point out that "it is possible that analyst recommendation revisions reflect news about a firm's competitive position in its industry". Boni and Womack (2006) argue that upgrades and downgrades, aggregated across all sell-side analysts for stocks within each industry, might generate significant abnormal net returns, though they do not explicitly examine the transaction costs. Motivated by Jegadeesh et al. (2004) and Boni and Womack (2006), we conduct an industry-based analysis in the third part of our empirical investigation on the performance of the upgrade and downgrade portfolios within each industry sector, identified by the twodigit Industry Classification Benchmark (ICB) codes (see "Appendix 2"). Specifically, we find no significantly positive abnormal net returns to the upgrade portfolio within any industry sector in any period of time. However, within two high-tech industry sectors, i.e., Health Care (ICB 45) and Technology (ICB 95) sectors, the downgrade portfolio generates significantly negative abnormal net returns, at least at the $5 \%$ level, in several periods of time. For example, within Technology sector, the significantly negative abnormal net returns vary from -3.21 basis points to -6.44 basis points from September 2001 to March 2003 , and vary from -2.44 basis points to -7.45 basis points from December 2006 to May 2010; similar evidence is found for the downgrade portfolio within Health Care sector. The reported incremental investment value is not only statistically significant, but also economically meaningful, suggesting the importance of controlling for the industry effect, which has never been explored in prior UK sell-side analyst research, to the best of our knowledge.

Thus far, our empirical investigation not only provides important evidence to complement the financial literature, but has significant implications for market participants. A natural question to ask is whether the reported portfolio performance in our empirical 
investigation is simply as a result of random chance, i.e., sell-side analysts' luck. Another major contribution of this study is for the first time to introduce a rolling window-based time-series bootstrapping simulation method (see details in "Appendix 3"), to distinguish sell-side analysts' luck from their skill (Fama 1998; Barber et al. 2001). Specifically, our simulated results confirm that, on average (1) the observed insignificantly positive abnormal returns to the upgrade portfolio could be attributed to sell-side analysts' lack of skill in making valuable upward revisions (even before transaction costs), rather than their bad luck; and (2) sell-side analysts have certain skill in making valuable downward revisions (before transaction costs) over some periods of time, while such skill is not sufficient to cover the size of transaction costs, irrespective of whether these revisions are made by high-ranking brokerage houses or not. More importantly, our simulated results confirm that sell-side analysts do possess superior skill in making downward revisions for stocks with high-tech related characteristics over some periods of time, even after transaction costs.

Overall, this study contributes to sell-side analyst research in several important respects. First, this study employs a calendar-time approach to assess the performance of investment strategies based on UK sell-side analyst recommendation revisions, using a uniquely insightful database, Morningstar Company Intelligence, which has never been examined before. In addition, our industry-based analyses show that it is likely to make profits by short selling stocks with downward revisions within two high-tech industry sectors, i.e., Health Care and Technology sectors, over some periods of time even after transaction costs, the results of which could be mainly attributed to the greater coverage and efforts made by sell-side analysts on high-tech firms with substantial intangible assets (Barth et al. 2001; Barron et al. 2002). Finally, we develop a time-series bootstrapping simulation method to test whether the observed time-varying investment performance is due to random chance (i.e., sell-side analysts' luck), though our simulation method can be applied to distinguish luck from skill when evaluating the calendar-time portfolio performance in other types of investments.

The remainder of this paper is organized as follows. Sections 2 and 3 describe data and research design, respectively. Section 4 presents empirical and simulated results, while the final section concludes.

\section{Data and sample description}

We obtain the real-time sell-side analyst recommendations from the Morningstar Extracted Data File: Historic Broker Recommendations for UK Registered and UK Listed Companies, uniquely created by Hemscott Company Guru, now part of Morningstar Company Intelligence. Each stock recommendation record contains information on the name of the covered firm, the name of the brokerage house issuing the recommendation, the recommendation starting and expiration dates, and a rating between 1 and 9. A rating of 1 reflects a strong buy, 2 a buy, 3 a weak buy, 4 a weak buy/hold, 5 a hold, 6 a hold/sell, 7 a weak sell, 8 a sell, and 9 a strong sell. We exclude stock recommendations that omit the name of brokerage houses, those without releasing the expiration dates, and/or those with data errors. Also, we require that (1) the gap between the starting and expiration dates of each recommendation is less than 1 year to ensure that the brokerage house is actively following the recommended stock; and (2) the relevant financial and accounting data of the covered firms are available from the London Share Price Database (LSPD). 
Our initial sample is comprised of 384,165 publicly available analyst recommendations made by 144 brokerage houses on 2905 distinct firms listed either on the main market of the LSE or on the AIM from January 1995 to June 2013. To allow for an easy and intuitive comparison with prior US studies, we reclassify all original analyst recommendations into five categories: Strong Buys (1 and 2; 44.99\%), Buys (3 and 4; 10.66\%), Holds (5; $32.43 \%$ ), Sells (6 and 7; 3.68\%), and Strong Sells (8 and 9; 8.24\%). Brown et al. (2009) argue that prior sell-side analyst research is generally hampered by a very low proportion of negative recommendations (Sells and Strong Sells), e.g., 3.0\% in the US (see, Barber et al. 2003). Table 1 shows that our Morningstar database overcomes this deficiency with much more negative recommendations, e.g., $11.92 \%$ of Sells and Strong Sells.

Sell-side analysts, however, often leave their stock recommendations unchanged for long periods of time; as a result, these stock recommendations become stale and less informative over time, potentially resulting in poor portfolio performance (see, Jegadeesh et al. 2004; Boni and Womack 2006; Jegadeesh and Kim 2006 and 2010; Hobbs et al. 2012). Therefore, our empirical investigation exclusively focuses on analyst recommendation revisions that convey more valuable information and have more predictive power over time. Table 2 presents the matrix of our final sample of 70,220 UK analyst recommendation revisions, i.e., 45.04\% are Strong Buys and Buys, 38.73\% are Holds, and 16.23\% are Sells and Strong Sells, similar to those reported elsewhere (see, e.g., Stickel 1995; Barber et al. 2001; Boni and Womack 2006). The inclusion of 23,235 (33.09\%) analyst recommendation revisions for 1042 dead firms in our sample also helps avoid the potential survivorship bias.

\section{Research design}

\subsection{Portfolio construction}

To evaluate the performance of calendar-time investment strategies, we construct two portfolios: (1) an upgrade portfolio, consisting of all stocks with upward revisions to Strong Buys or Buys from previous Strong Sells, Sells, or Holds; and (2) a downgrade portfolio, consisting of all stocks with downward revisions to Strong Sells, Sells, or Holds from previous Strong Buys or Buys. Specifically, to construct the upgrade portfolio, for each brokerage house, we identify upward revisions to Strong Buys or Buys from previous Holds, Sells, or Strong Sells during our sample period. The upgrade portfolio is updated daily; for each upward revision, the recommended stock enters the portfolio at the close of trading on the day the revision is announced. If an upward revision is announced on a non-trading day, the recommended stock is added into the upgrade portfolio at the close of the next trading day, and remains in the portfolio until the stock is either downgraded or dropped from coverage by the brokerage house. ${ }^{4}$ If a stock is recommended by more than one brokerage house on a given date, then that stock will appear multiple times in the upgrade portfolio on that date, once for each brokerage house. The downgrade portfolio is constructed in an analogous daily fashion.

\footnotetext{
4 A recent study of Rees et al. (2017) argues that sell-side analysts tend to strategically time the release of their recommendation revisions, in particular, to make downgrades on the weekends, as investor and media attention to analyst recommendation revisions is reduced on the weekends. However, this is not a serious concern about our sample, as only a total of $427(0.76 \%)$ analyst recommendation revisions (187 upwards revisions and 240 downward revisions) are released on the weekends.
} 


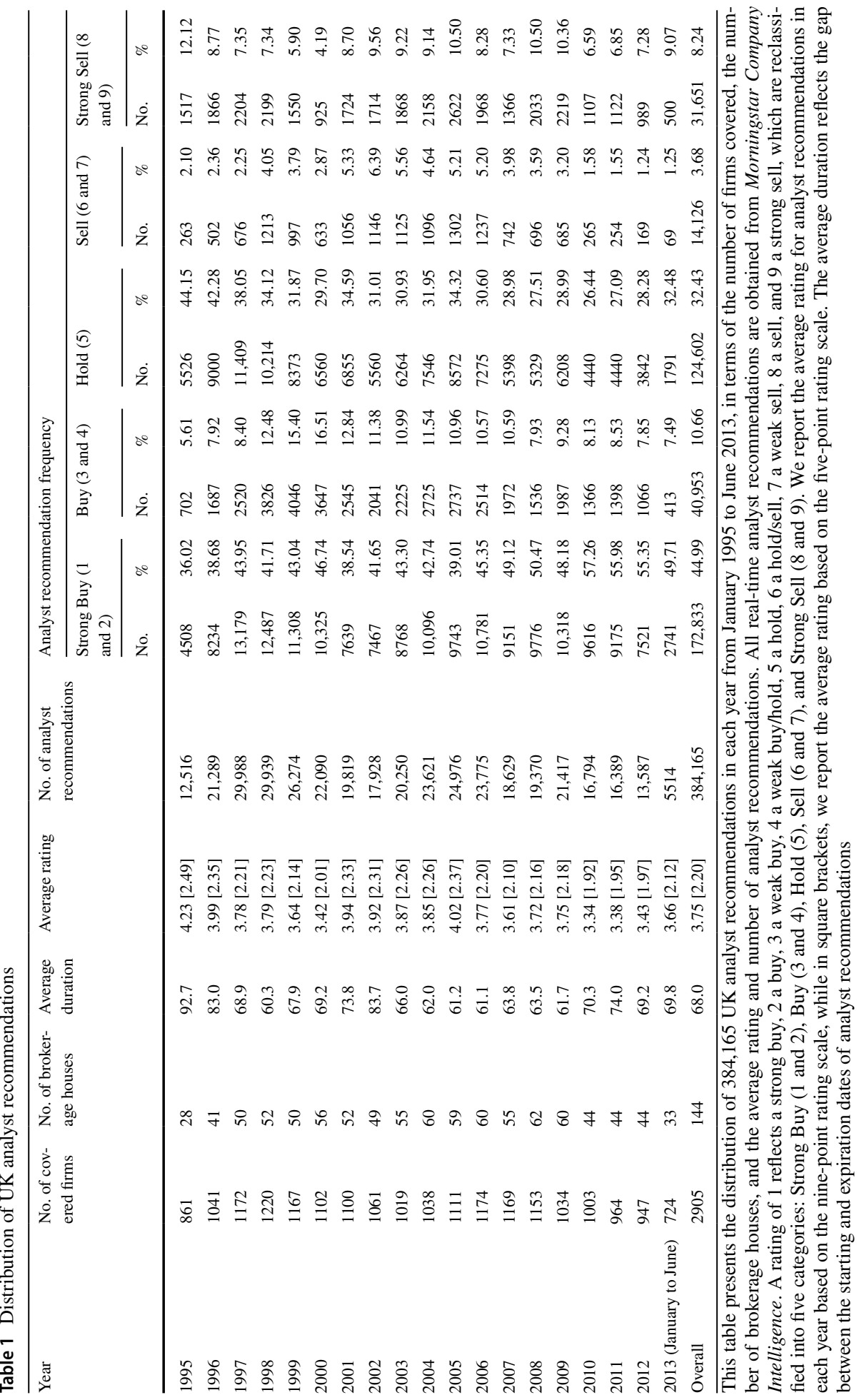


Table 2 Matrix of UK analyst recommendation revisions

\begin{tabular}{llllllll}
\hline From old rating & \multicolumn{2}{l}{ To new rating } & & & Total & $\%$ \\
\cline { 2 - 6 } & $\begin{array}{l}\text { Strong } \\
\text { Buy (1 } \\
\text { and 2) }\end{array}$ & Buy (3 and 4) & Hold (5) & Sell (6 and 7) & $\begin{array}{l}\text { Strong } \\
\text { Sell (8 } \\
\text { and 9) }\end{array}$ & & \\
& & & & & & \\
\hline Strong Buy (1 and 2) & - & 5923 & 14,506 & 396 & 977 & 21,802 & 31.05 \\
Buy (3 and 4) & 5756 & - & 5242 & 682 & 204 & 11,884 & 16.92 \\
Hold (5) & 12,745 & 5267 & - & 2596 & 4927 & 25,535 & 36.36 \\
Sell (6 and 7) & 298 & 630 & 2410 & - & 844 & 4182 & 5.96 \\
Strong Sell (8 and 9) & 833 & 172 & 5043 & 769 & - & 6817 & 9.71 \\
Overall & 19,632 & 11,992 & 27,201 & 4443 & 6952 & 70,220 & - \\
\% & 27.96 & 17.08 & 38.73 & 6.33 & 9.90 & - & 100.00 \\
\hline
\end{tabular}

This table presents the matrix of 70,220 UK analyst recommendation revisions from January 1995 to June 2013. All real-time analyst recommendations are obtained from Morningstar Company Intelligence. A rating of 1 reflects a strong buy, 2 a buy, 3 a weak buy, 4 a weak buy/hold, 5 a hold, 6 a hold/sell, 7 a weak sell, 8 a sell, and 9 a strong sell, which are reclassified into five categories: Strong Buy (1 and 2), Buy (3 and 4), Hold (5), Sell (6 and 7), and Strong Sell (8 and 9)

Panel A of Table 3 presents the distribution of upward and downward revisions in the upgrade and downgrade portfolios, respectively, by the year of analyst recommendation revisions. The total number of sell-side analyst recommendation revisions included in the upgrade and downgrade portfolios, 56,075 $(25,701+30,374)$, appears to be less than the total number of 70,220, as shown in Table 2, which is not surprising, however. The upgrade portfolio does not include stocks with upward revisions from Strong Sells to Holds, from Strong Sells to Sell, and from Sells to Holds, as they can also be interpreted as negative recommendations, while the downgrade portfolio does not include stocks with downward revisions from Strong Buy to Buy, as they can also be interpreted as positive recommendations (see, Stickel 1995; Brown et al. 2009). Panel B of Table 3 shows that no seasonal patterns are evident in the dataset.

\subsection{Portfolio performance evaluation}

We calculate the daily value-weighted return from the upgrade and downgrade portfolios on date $t, R_{p, t}$, as follows:

$$
R_{p, t}=\sum_{i=1}^{n_{p, t-1}} \omega_{i, t-1} \times R_{i, t},
$$

where $R_{i, t}$ represents the daily return for the recommended stock $i$ on date $t^{5} ; n_{p, t-1}$ represents the number of revisions in the portfolio $p$ as of the close of trading on date $t-1$; and

\footnotetext{
5 We explicitly exclude the return on the first trading day as many investors, particularly small investors, tend to react to information with a delay, as "it is impractical for them to engage in the daily portfolio rebalancing that is needed to respond to the changes" (Barber et al. 2001, p. 534). The value-weighted returns enable us to better capture the economic significance of our results, while the equal-weighted returns are, on average, biased upward due to the bid-ask bounce (see, Barber et al. 2001, 2003), that is, the returns of large size firms will be more heavily represented in the aggregate returns than those of small size firms (see, Lyon et al. 1999).
} 


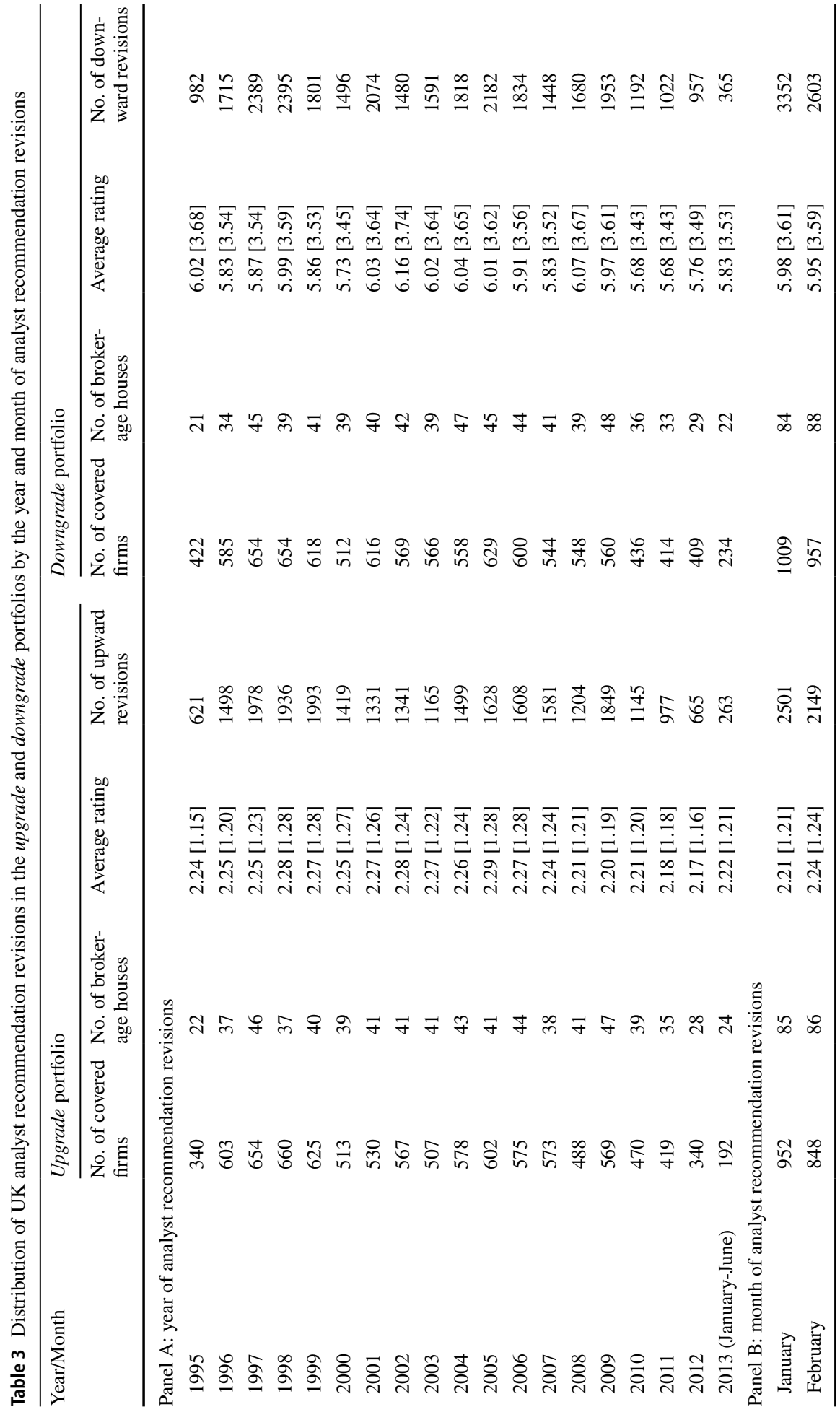




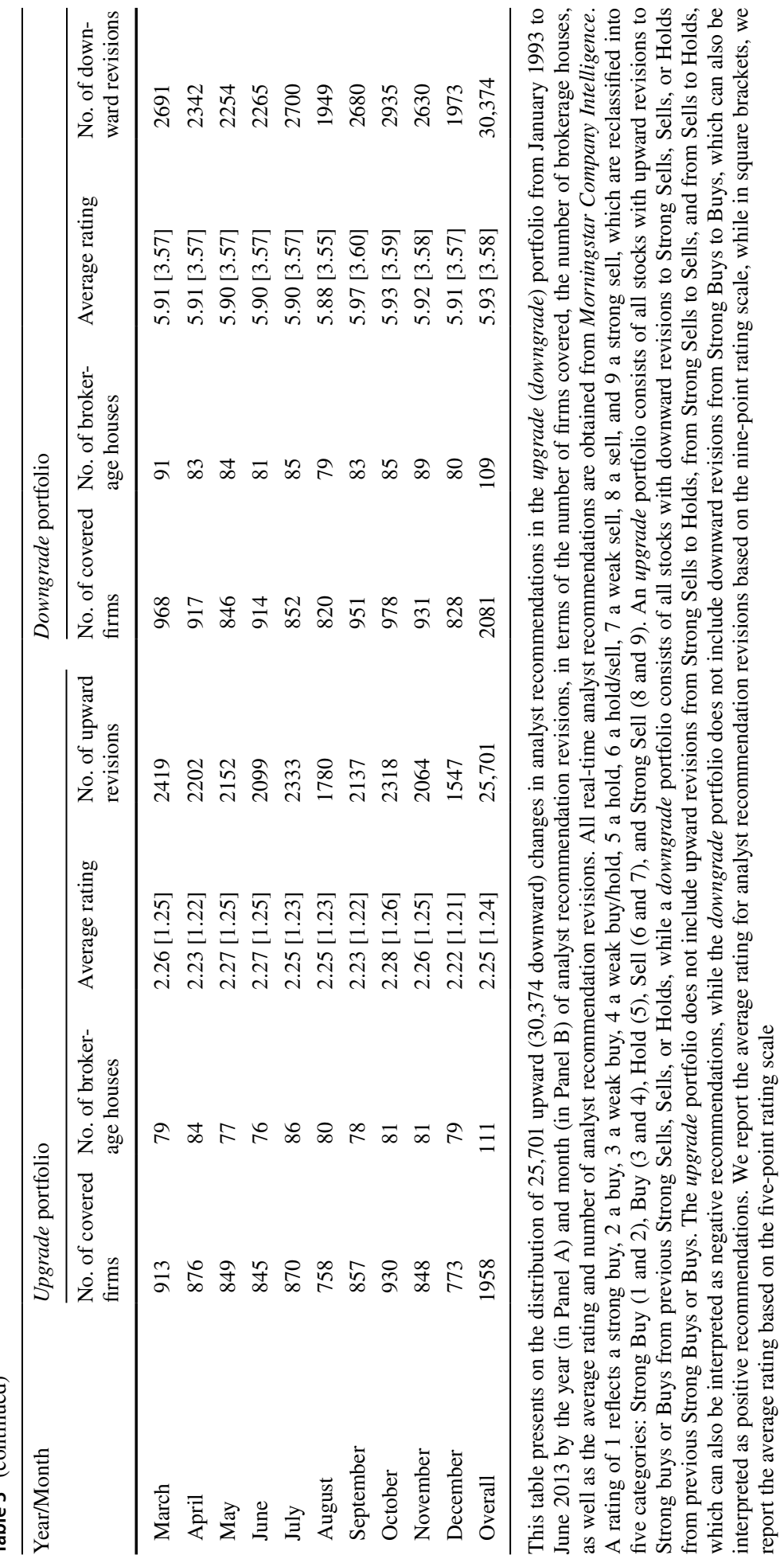


$\omega_{i, t-1}$ represents the weight of stock $i$ in the portfolio $p$ on date $t-1$, that is, the market value of stock $i$ as of the close of trading on date $t-1$, divided by the aggregate market value of all stocks in the portfolio as of the close of trading on date $t-1$.

The abnormal return gross of transaction costs is estimated as the intercept term of $\alpha_{p}$ derived from the recent Fama and French (2015) five-factor model:

$$
R_{p, t}-R_{f, t}=\alpha_{p}+\beta_{p}\left(R_{m, t}-R_{f, t}\right)+s_{p} S M B_{t}+h_{p} H M L_{t}+r_{p} R M W_{t}+c_{p} C M A_{t}+\varepsilon_{p, t},
$$

where $R_{m, t}$ and $R_{f, t}$ represent the daily returns on the FTSE All-Share Index and on a 3-month UK T-bill, respectively; $S M B_{t}, H M L_{t}, R M W_{t}$, and $C M A_{t}$ represent the daily returns on zero-investment factor-mimicking portfolios for size, book-to-market (B/M), operating profitability, and investment, respectively ${ }^{6}$; and $\varepsilon_{p, t}$ represents the error term.

We estimate Eq. (2) repeatedly on a rolling window basis - a 1-year window length rolling one trading day forward-to track the performance of the underlying variables over time. Specifically, the first rolling window is from January 3, 1995 to December 29, 1995, covering 252 trading days, the typical number of trading days in a year in the UK stock market. Then a new observation (trading day) is added to the rolling window, while the first one is dropped, that is, we update the rolling window to include observations from January 4, 1995 to January 2, 1996, and so forth. In each rolling window, the five-factor regression yields parameter estimates of $\alpha_{p}, \beta_{p}, s_{p}, h_{p}, r_{p}$, and $c_{p}$; a significantly positive (negative) $\alpha_{p}$ indicates that the upgrade (downgrade) portfolio is profitable after controlling for risk factors of market, size, value, operating profitability, and investment. This calculation, therefore, generates a time series of 4420 daily abnormal gross returns to the upgrade or downgrade portfolio from January 1996 to June 2013.

To rule out the concern on the poor model of asset pricing-i.e., the newly introduced factors of operating profitability and investment in the Fama and French (2015) five-factor model might not be effective in the UK stock market and the momentum effect is also ignored (see, Barber et al. 2001; Brookfield et al. 2015) —we further estimate the CAPM, the Fama and French (1993) three-factor model, and the Carhart (1997) four-factor model:

$$
\begin{gathered}
R_{p, t}-R_{f, t}=\alpha_{p}+\beta_{p}\left(R_{m, t}-R_{f, t}\right)+\varepsilon_{p, t} ; \\
R_{p, t}-R_{f, t}=\alpha_{p}+\beta_{p}\left(R_{m, t}-R_{f, t}\right)+s_{p} S M B_{t}+h_{p} H M L_{t}+\varepsilon_{p, t} ; \\
R_{p, t}-R_{f, t}=\alpha_{p}+\beta_{p}\left(R_{m, t}-R_{f, t}\right)+s_{p} S M B_{t}+h_{p} H M L_{t}+m_{p} M O M_{t}+\varepsilon_{p, t},
\end{gathered}
$$

where $\mathrm{MOM}_{t}$ represents the daily return on a zero-investment factor-mimicking portfolio for price momentum ${ }^{7}$; other variables are as defined in Eq. (2). In addition to parameter estimates of $\alpha_{p}$ and $\beta_{p}$ generated in the single-factor regression, the three-factor regression yields parameter estimates of $s_{p}$ and $h_{p}$, while the four-factor regression yields parameter estimates of $s_{p}, h_{p}$, and $m_{p}$.

\footnotetext{
${ }^{6}$ Fama and French $(2015$, p. 1) argue that their five-factor model captures "the size, value, profitability, and investment patterns in average stock returns". We construct the five factors in the UK stock market, strictly following Fama and French (Fama and French 1993, 2015).

${ }^{7}$ We construct the momentum factor in the UK stock market, following Carhart (1997). For robustness purposes, we also estimate the CAPM, the Fama and French (1993) three-factor model, and the Carhart (1997) four-factor model, using the daily returns on market, size, value, and momentum obtained from the Xfi Centre for Finance and Investment at University of Exeter (see, Gregory et al. 2013). Our results remain qualitatively the same, which are not reported for the sake of brevity, but are available on request.
} 


\subsection{Transaction costs}

Timmermann and Granger (2004, p. 19) argue that return predictability "has to be seen in relation to the transaction costs of the asset. Predictable patterns only invalidate the EMH once they are large enough to cover the size of transaction costs." Keim and Madhavan (1998) categorize transaction costs into explicit costs (e.g., brokerage commissions and taxes) and implicit costs (e.g., bid-ask spread and market impact of trading). Hudson et al. (1996) show that the total single-trip transaction costs in the UK for the most favored of investors is upward of $0.5 \%$, including government stamp duty of $0.25 \%$, negotiated brokerage commission of $0.05 \%$ (soft commissions could be zero if alternative services are offered in lieu of cash), and bid-ask spread of $0.25 \%$. Based on a relatively cautious estimate of the average single-trip transaction costs in the UK for purchasing stocks at $0.75 \%$ and for short selling stocks at $1.5 \%,{ }^{8}$ we further measure the corresponding average daily portfolio turnover multiplied by transaction costs in each rolling window.

Specifically, the daily turnover for the upgrade portfolio $p$ on the trading date $t$ is defined as the percentage of stocks in the portfolio as of the close of trading on date $t-1$ that has been sold off as of the close of trading on date $t$. That is, following Barber et al. (2001), we measure the daily turnover as the percentage of the portfolio that has been turned over into some other set of stocks on date $t$. First, for each stock $i$ in the portfolio $p$ as of the close of trading on date $t-1$, we calculate its fraction of the portfolio, $G_{i, t}$, at the end of trading on date $t$ without accounting for portfolio rebalancing:

$$
G_{i, t}=\omega_{i, t-1} \times\left(1+R_{i, t}\right) / \sum_{i=1}^{n_{p, t-1}} \omega_{i, t-1} \times\left(1+R_{i, t}\right)
$$

where, as before, $R_{i, t}$ represents the daily return for the recommended stock $i$ on date $t$; $n_{p, t-1}$ represents the number of revisions in the portfolio $p$ as of the close of trading on date $t-1$; and $\omega_{i, t-1}$ represents the weight of stock $i$ in the portfolio $p$ on date $t-1$, that is, the market value of stock $i$ as of the close of trading on date $t-1$, divided by the aggregate market value of all stocks in the portfolio as of the close of trading on date $t-1$.

Second, $G_{i, t}$ is compared to the actual fraction, that is, stock $i$ makes up of portfolio $p$ as of the close of trading on date $t$, after accounting for any portfolio rebalancing. Finally, the change in the percentage holding of each stock on date $t-1$ is summed, generating the portfolio turnover on date $t, T U R N_{p, t}{ }^{9}$ :

$$
\operatorname{TURN}_{p, t}=\sum_{i=1}^{n_{p, t}}\left|G_{i, t}-F_{i, t}\right|,
$$

\footnotetext{
${ }^{8}$ Barber et al. (2001) report that the abnormal net returns are not significantly greater than zero after accounting for the average single-trip transaction costs of $0.65 \%$ in the US. Despite the lack of readily available data regarding short selling costs in the UK, we assume a short selling cost of $0.75 \%$, according to Ellis and Thomas (2004) and Li et al. (2009).

9 We calculate the portfolio turnover accounting for both increase and decrease in stock weight. For example, we adjust the upgrade portfolio by buying new stocks with upward revisions and simultaneously selling existing stocks when their upward revisions are dropped or downgraded on a daily basis; the increase in stock weight equals to the decrease in stock weight at the portfolio level (see, Barber et al. 2001). Therefore, the total portfolio turnover $=2 \times$ the decrease (or increase) in stock weight: $\sum_{i=1}^{n_{p, t}}\left|G_{i, t}-F_{i, t}\right|=\sum_{i=1}^{n_{p, t}} \max \left\{\left(G_{i, t}-F_{i, t}\right), 0\right\} \times 2$.
} 
where $n_{p, t}$ represents the number of revisions in the portfolio $p$ as of the close of trading on date $t ; G_{i, t}$ represents the calculated weight of stock $i$ in the portfolio $p$ as of the close of trading on date $t-1$ without accounting for portfolio rebalancing; and $F_{i, t}$ represents the actual weight that stock $i$ in the portfolio $p$ at the end of trading on date $t$ after any portfolio rebalancing.

Finally, in each rolling window, we calculate the abnormal net return as the abnormal gross return less the estimated single-trip transaction costs multiplied by the corresponding daily portfolio turnover ${ }^{10}$ :

Abnormal net return $=$ Abnormal gross return $\left(\alpha_{p}\right)-$ single-trip transaction $\cos t s \times T U R N_{p, t}$.

\section{Empirical and simulated results}

In this section, we focus on presenting the empirical and simulated results under the Fama and French (2015) five-factor model, though our results remain qualitatively unchanged under the CAPM, the Fama and French (1993) three-factor model, and the Carhart (1997) four-factor model. These results are not presented for the sake of brevity, but are available on request.

\subsection{Time-varying portfolio performance}

\subsubsection{Abnormal gross returns}

Figure 1a illustrates the time-varying daily abnormal returns gross of transaction costs to the upgrade portfolio, along with the corresponding $t$-statistics. Overall, the upgrade portfolio does not generate any significantly positive abnormal gross returns in any period of time, but generate significantly negative abnormal gross returns in several periods of time. Specifically, the abnormal gross returns initially fluctuate around zero, and then become significantly negative, at least at the 5\% level, from August 2001 to July 2003, ranging from -3.80 basis points to -6.49 basis points. After that, the significantly negative abnormal gross returns are also observed in two short periods of time: (1) from August 2006 to January 2007 , ranging from -2.42 basis points to -4.27 basis points; and (2) from August 2008 to November 2008, ranging from -4.55 basis points to -6.02 basis points. Our empirical results suggest that upgrades are generally valueless in the UK, as they could not generate significantly positive abnormal returns (even before transaction costs). Therefore, from an investor's perspective, it is unlikely to make profits by purchasing stocks with upward revisions in any period of time and, even worse, it is likely to suffer significant losses over some periods of time.

Figure $1 \mathrm{~b}$ illustrates the time-varying daily abnormal returns gross of transaction costs to the downgrade portfolio, along with the corresponding $t$-statistics. Importantly, the downgrade portfolio generates significantly negative abnormal gross returns in several periods of time, at least at the $5 \%$ level. For example, we find significantly negative abnormal gross returns, which range from -3.50 basis points to -6.40 basis points from

\footnotetext{
10 The unreported daily turnover for the upgrade portfolio ranges from 1.41 to $1.83 \%$, with an average of $1.61 \%$ over the whole sample period; the average daily turnover for the downgrade portfolio ranges from 1.37 to $1.89 \%$, with an average of $1.63 \%$, which is close to that reported in the US (see, Barber et al. 2001).
} 
(a)
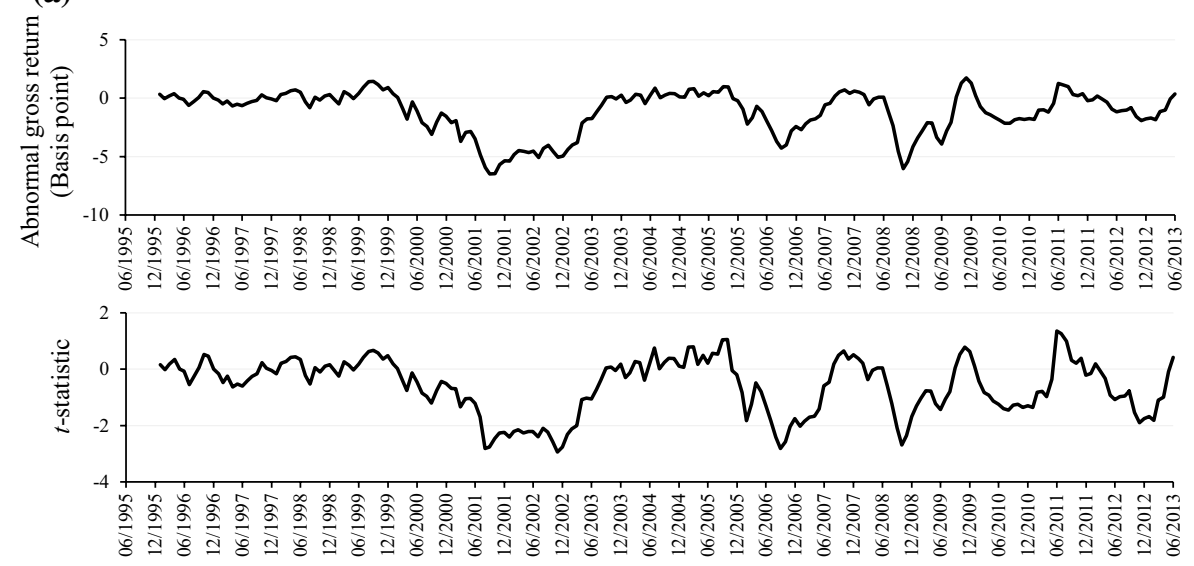

(b)

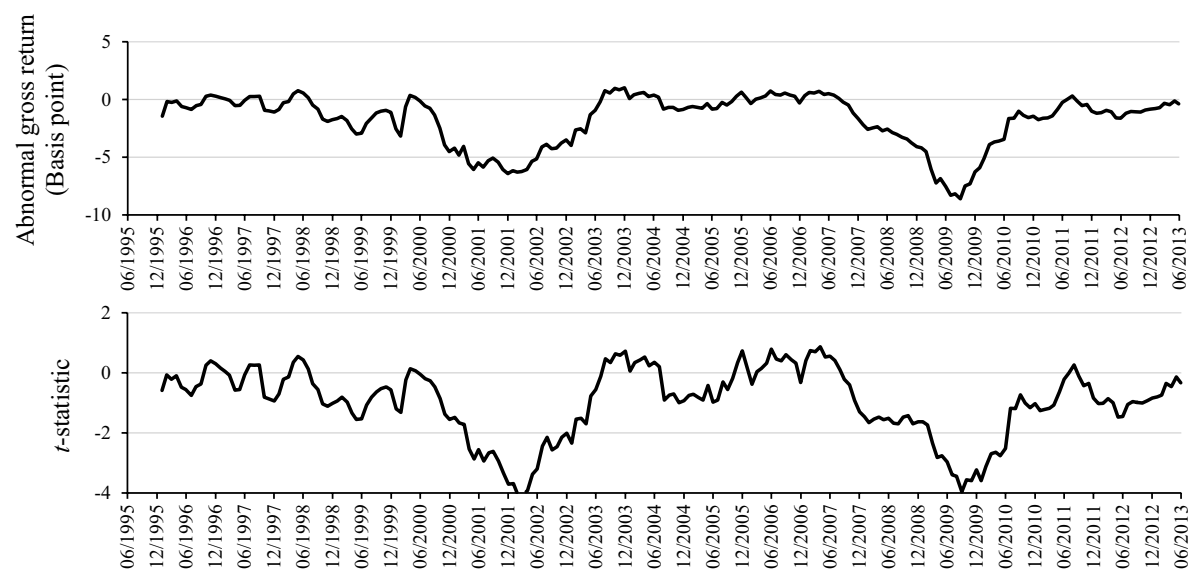

Fig. 1 The time-varying daily abnormal gross returns to the a upgrade and $\mathbf{b}$ downgrade portfolios and the corresponding $t$-statistics under the Fama and French (2015) five-factor model, using the whole sample of $\mathrm{UK}$ analyst recommendation revisions

April 2001 to January 2003, and range from -3.45 basis points to -8.59 basis points from March 2009 to June 2010. This suggests that, on average, downgrades have certain investment value and that it is likely for investors to make profits by short selling stocks with downward revisions over some periods of time (before transaction costs).

\subsubsection{Abnormal net returns}

Figures $2 \mathrm{a}, \mathrm{b}$ illustrates the time-varying average daily abnormal returns net of transaction costs to the upgrade (downgrade) portfolio, along with the corresponding $t$-statistics. We find no significantly positive (negative) abnormal net returns to the upgrade (downgrade) portfolios in any period of time, suggesting that it is unlikely for investors to make profits by purchasing (short selling) stocks with upward (downward) revisions after taking a 
(a)
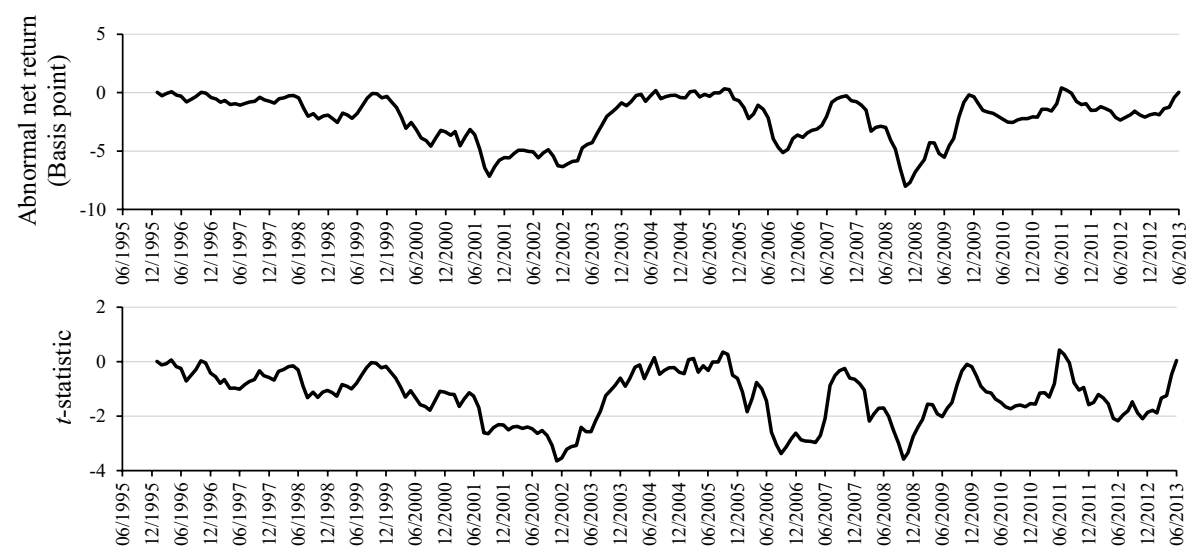

(b)
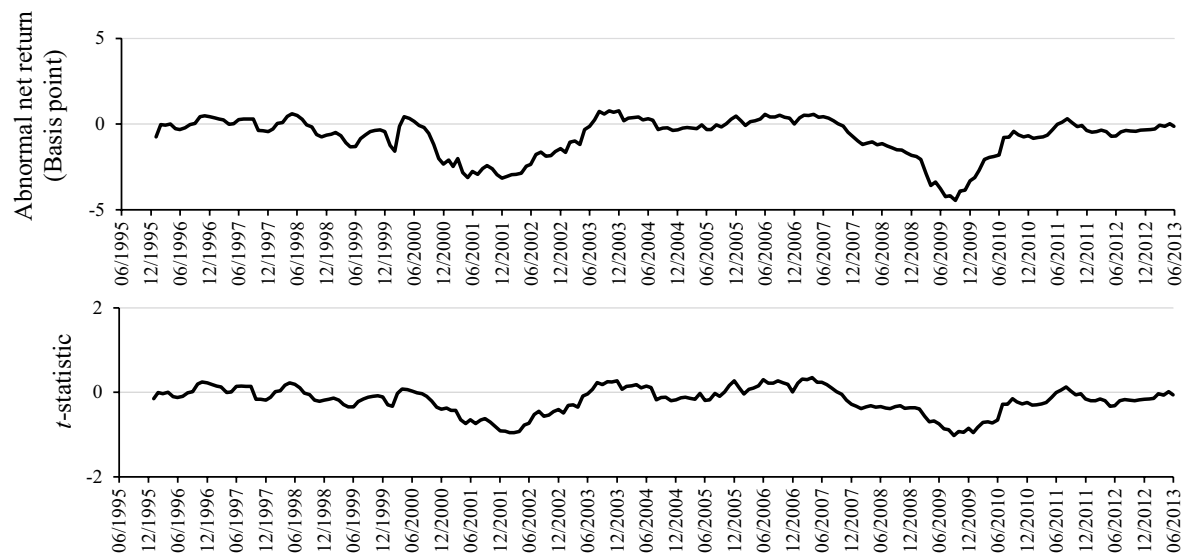

Fig. 2 The time-varying daily abnormal net returns to the $\mathbf{a}$ upgrade and $\mathbf{b}$ downgrade portfolios and the corresponding $t$-statistics under the Fama and French (2015) five-factor model, using the whole sample of UK analyst recommendation revisions

reasonable level of transaction costs into account, in line with Barber et al. (2001). Therefore, the observed market inefficiencies disappear after transaction costs, that is, the significantly negative abnormal gross returns to the downgrade portfolios in several periods of time, as illustrated in Fig. 1b, are actually not exploitable by investors. ${ }^{11}$

\footnotetext{
${ }^{11}$ We thank an anonymous reviewer for suggesting that the transaction costs should be taken into account for both the portfolio and benchmarks when calculating the abnormal net return of the upgrade and downgrade portfolios. Based on the gross Fama and French (2015) five factors in the UK, we further construct the tradable factors. Specifically, the net return of each tradable factor portfolio is measured as the gross return of the corresponding factor portfolio less the portfolio turnover multiplied by transaction costs. Following Novy-Marx and Velikov (2016), we rebalance the underlying portfolios for the Fama and French (2015) factors annually, at the end of every June. We then reestimate the abnormal net return to the upgrade or downgrade portfolio by regressing the net portfolio return (the gross portfolio return net of transaction costs) against the tradable Fama and French (2015) five factors. Our overall conclusions hold up fairly well; our results based on the tradable Fama and French (2015) five factors are not presented to save space, but are available on request.
} 


\subsection{Alternative investment strategies}

\subsubsection{High-ranking brokerage houses}

A growing body of sell-side analyst research shows the existence of skill differences among sell-side analysts, and those sell-side analysts with higher reputation (or star sellside analysts) are more able to make more valuable stock recommendations (see, Stickel 1995; Hong and Kubik 2003; Fang and Yasuda 2014; Kucheev et al. 2017). Ljungqvist et al. (2009) argue that the ranking of sell-side analysts in the Institutional Investor annual poll is the most important driver of their career outcomes. If investors realize that an analyst provides them with wrong information on purpose, the damage to the analyst's reputation would be immediate and long-lasting. Sell-side analysts, as repetitive players in the capital markets, obtain and accumulate their reputation capital, and invariably attempt to protect their reputation capital by reducing the probability of becoming involved with misleading stock recommendations. As more prestigious brokerage houses are able to attract and employ star sell-side analysts, we expect analyst recommendation revisions made by high-ranking brokerage houses to be more valuable. ${ }^{12}$

Specifically, we construct two alternative upgrade and downgrade portfolios, using a subsample of 11,016 analyst recommendation revisions made exclusively by the top 5 brokerage houses, identified by their 3-year moving average $(t-3, t-2, t-1)$ of positions on the annual All-Europe Research Team published by Institutional Investor (see details in "Appendix 1"). Repeating all empirical analyses in Sect. 4.1, we find quite similar results to those using the whole sample. For example, Figs. $3 \mathrm{a}$ and $4 \mathrm{a}$ show that the upgrade portfolio fails to generate any significantly positive abnormal gross (net) returns in any period of time before (after) transaction costs. Figure 3b shows that the downgrade portfolio generates significantly negative abnormal gross returns, at least at the $5 \%$ level, which range from -3.74 basis points to -8.57 basis points from January 2001 to March 2003, and range from -3.79 basis points to -8.68 basis points from December 2008 to March 2010 . However, these observed significantly negative abnormal returns to the downgrade portfolio disappear after transaction costs (see Fig. 4b).

Overall, we conclude that the reputation of brokerage houses does not play an important role in making valuable upward and downward revisions in the UK. That is, it is unlikely for investors to make profits (after transaction costs) by following analyst recommendation revisions in the UK, irrespective of whether they are made by highranking brokerage houses or not. This seems different from that reported in the US, but the discrepancy could be explained by the less influence of the annual All-European Research Team published by Institutional Investor on UK sell-side analysts' career concern, compared with the influence of its US counterpart.

\footnotetext{
12 The Morningstar database does ide information on individual sell-side analysts issuing stock recommendations, so we focus on the reputation of brokerage houses, which is supposed to be positively correlated with the reputation of individual sell-side analysts (see Brown et al. 2009).
} 

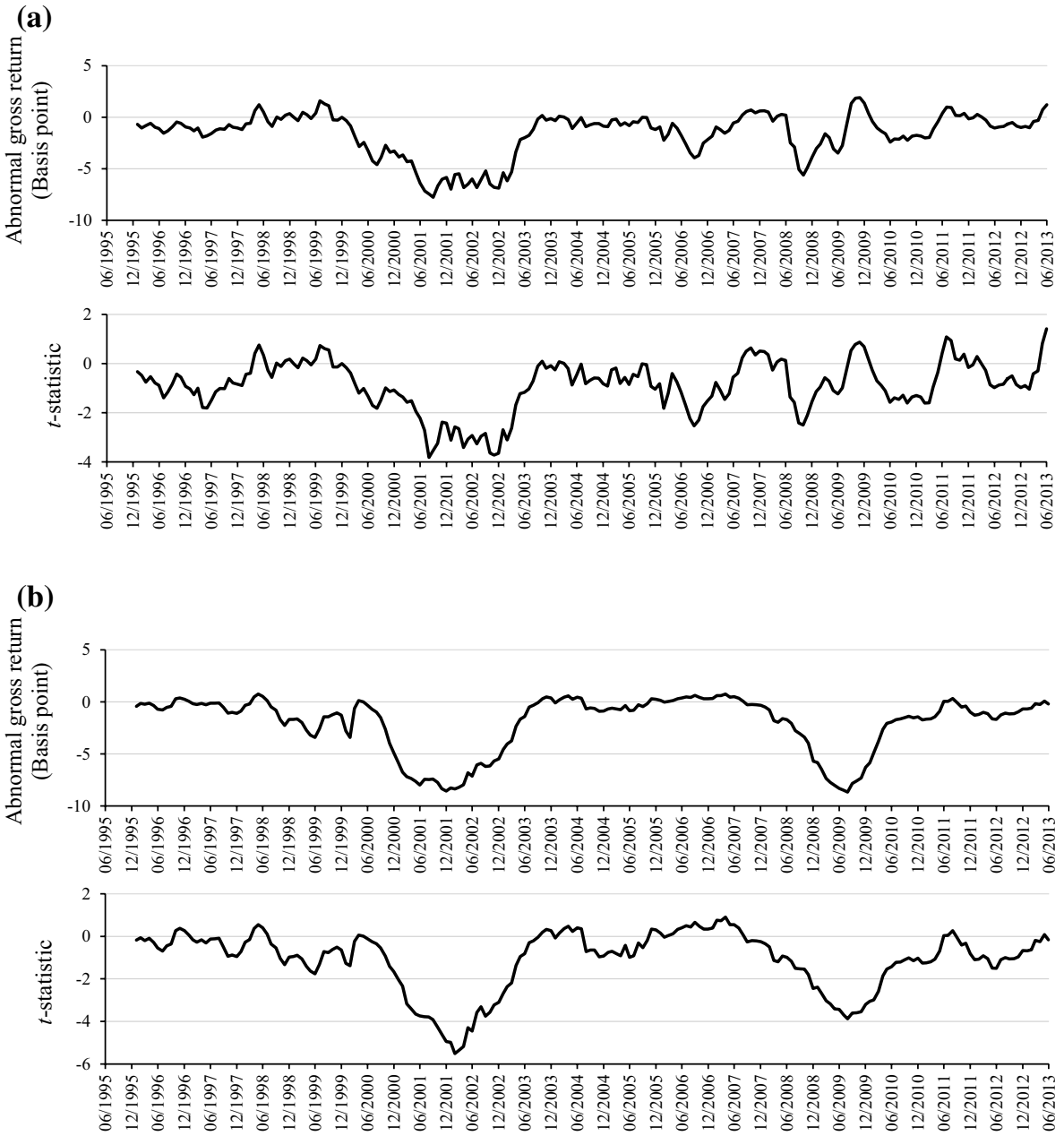

Fig. 3 The time-varying daily abnormal gross returns to the a upgrade and $\mathbf{b}$ downgrade portfolios and the corresponding $t$-statistics under the Fama and French (2015) five-factor model, using the subsample of UK analyst recommendation revisions made by the top 5 brokerage houses

\subsubsection{Industry-based investment strategies}

Prior sell-side analyst research emphasizes the importance of controlling for various firmspecific characteristics of the recommended stocks, e.g., size, value, trading volume, price momentum, earnings, and so on (see, Stickel 1995; Womack 1996; Jegadeesh et al. 2004; Anderson et al. 2017). Little attention has been paid to industry, though it has been well demonstrated to have predictive value for stock returns (see, Markowitz and Grinblatt 1999; Boni and Womack 2006). In this subsection, we conduct an industry-based analysis to assess whether analyst recommendation revisions for stocks within specific industry sectors in the UK can make large enough profits to cover the size of transaction costs. 
(a)
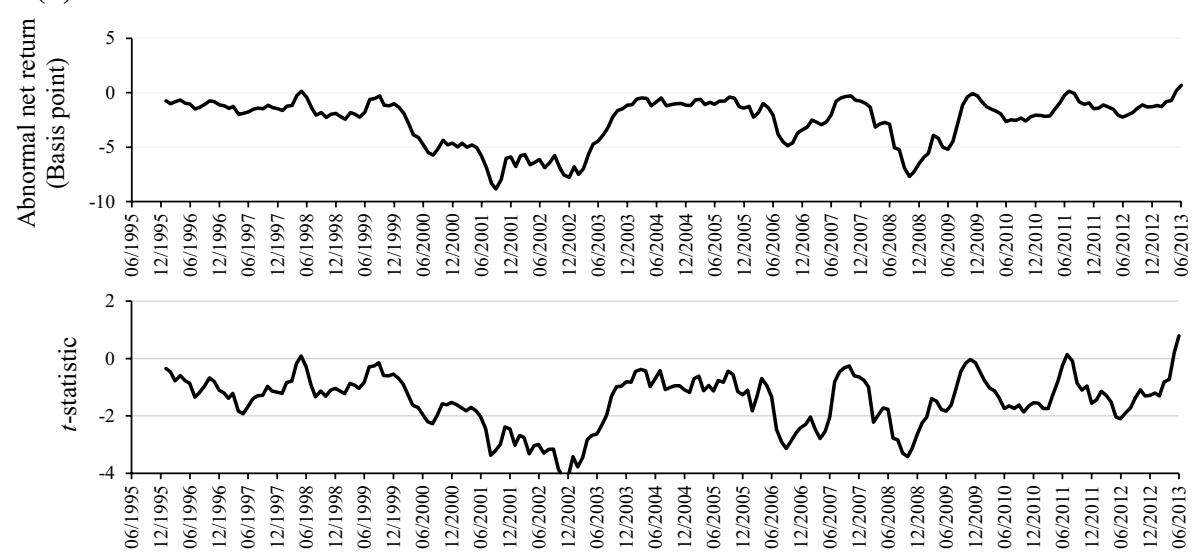

(b)
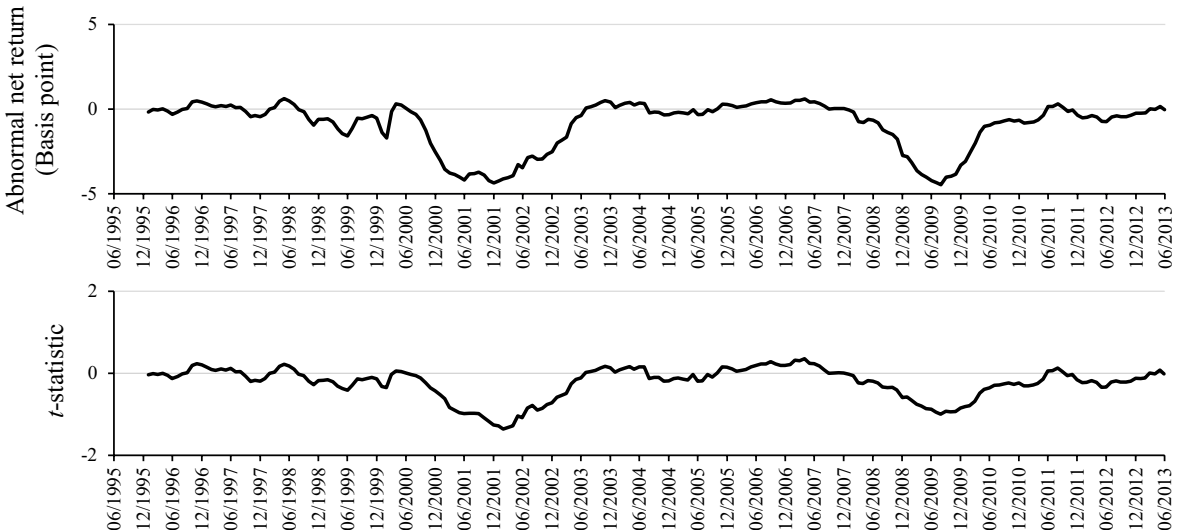

Fig. 4 The time-varying daily abnormal net returns to the a upgrade and $\mathbf{b}$ downgrade portfolios and the corresponding $t$-statistics under the Fama and French (2015) five-factor model, using the subsample of UK analyst recommendation revisions made by the top 5 brokerage houses

Overall, we find no significantly positive abnormal net returns to the upgrade portfolio within any industry sector in any period of time, again suggesting that upgrades have no investment value in the UK, consistent with our early results (see Figs. 2a, 4a). However, we find some important evidence showing significantly negative abnormal net returns to the downgrade portfolio over some periods of time within two high-tech industry sectors, i.e., Health Care (ICB 45) and Technology (ICB 95) sectors. In this subsection, we focus on presenting the time-varying daily abnormal net returns to the downgrade portfolios within Health Care and Technology sectors. The insignificantly positive (negative) abnormal returns to the upgrade (downgrade) portfolio within other industry sectors are not reported to save space, but are available on request.

Figure 5a, b illustrates the time-varying daily abnormal net returns to the downgrade portfolio, along with the corresponding $t$-statistics, within Health Care and Technology sectors, respectively. Specifically, Fig. 5a shows that, within Health Care sector, the 

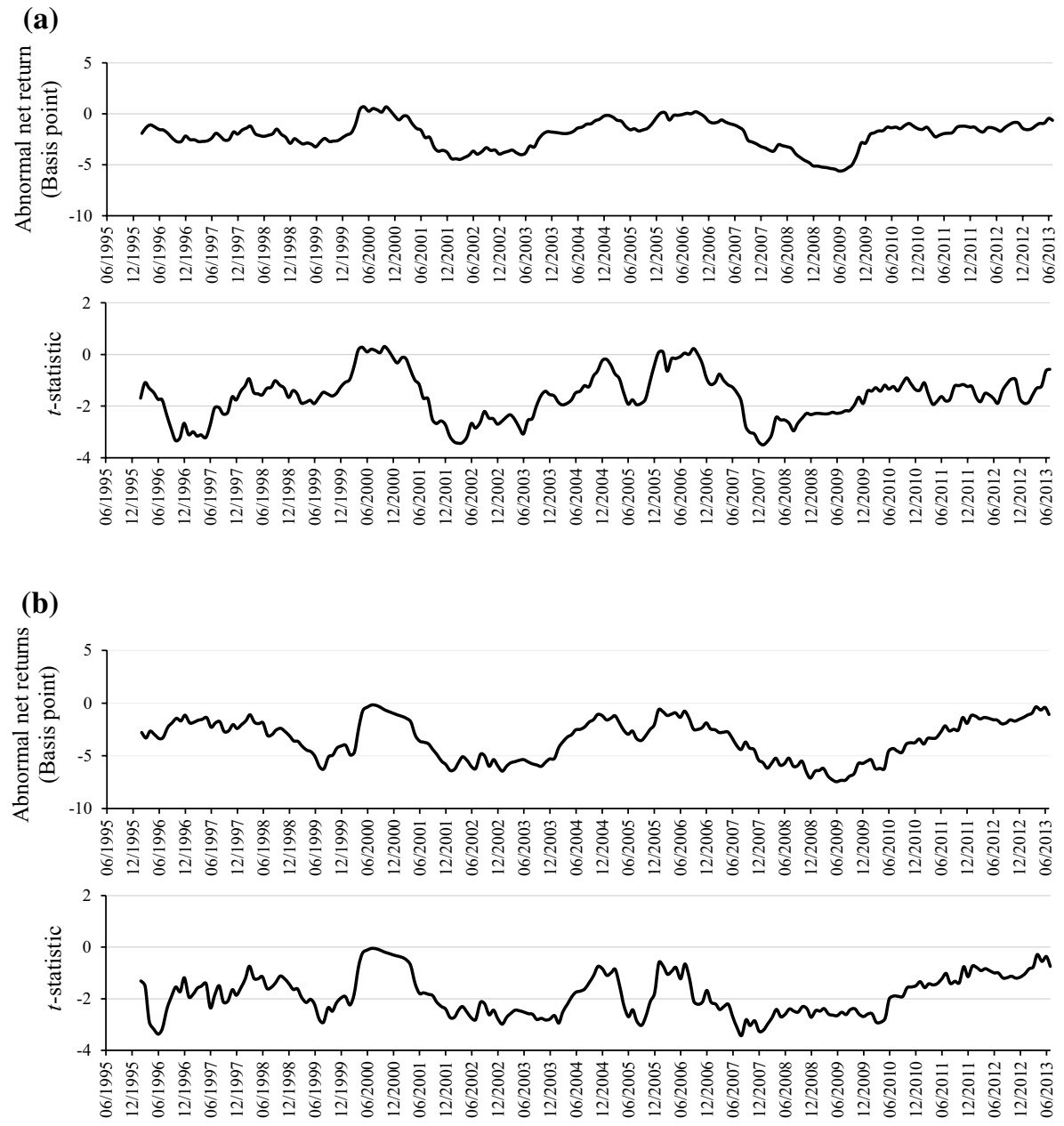

Fig. 5 The time-varying daily abnormal net returns to the downgrade portfolio and the corresponding $t$-statistics under the Fama and French (2015) five-factor model, within a Health Care (ICB 45) sector and b Technology (ICB 95) sector

downgrade portfolio generates significantly negative abnormal net returns, at least at the $5 \%$ level, in several periods of time. For example, the significantly negative abnormal net returns range from -1.94 basis points to -2.73 basis points from July 1996 to September 1997, range from -2.51 basis points to -4.47 basis points from August 2001 to August 2003 , and range from -2.58 basis points to -5.61 basis points from August 2007 to August 2009. Similarly, within Technology sector, the significantly negative abnormal net returns to the downgrade portfolio are observed in several periods of time, at least at the $5 \%$ level (see Fig. 5b). For example, the significantly negative abnormal net returns range from -3.21 basis points to -6.44 basis points from September 2001 to March 2003, and range from -2.44 basis points to -7.45 basis points from December 2006 to May 2010 .

These negative abnormal net returns to the downgrade portfolio within the two industry sectors are not only statistically significant, but also economically meaningful, suggesting 
the importance of controlling for the industry effect. From an investor's perspective, it is likely to make profits by short selling stocks with downward revisions with high-tech related characteristics over some periods of time, even after transaction costs, though upward revisions are valueless in any industry sector. Our results confirm that short signals are more valuable than long signals (see, e.g., Barber et al. 2001; Jegadeesh et al. 2004; Ryan and Taffler 2006). ${ }^{13}$

Furthermore, our results could be mainly attributed to the greater coverage and efforts made by sell-side analysts on high-tech firms (Barth et al. 2001; Barron et al. 2002; Hirshleifer et al. 2018). More specifically, high-tech firms have more unrecognized intangible assets, which reflect greater economic benefits from knowledge-based activities in the future. These high-tech firms, therefore, attract more attention from investment community and enjoy greater coverage; analyst coverage, in turn, improves the efficiency of communicating private information to investors (see, Barron et al. 2002; Sun 2011).

Given that intangible assets are typically unrecognized in the financial statements, hightech firms are associated with more complex information, which provides opportunities for sell-side analysts to benefit from the application of their expertise (Barth et al. 2001; Barron et al. 2002; Hirshleifer et al. 2018). Sell-side analysts, therefore, expend more intense efforts to cover high-tech firms. In particular, the rapid development of the Internet has greatly enhanced the accessibility of various information, helping sell-side analysts make more valuable recommendations for stocks with high-tech related characteristics (Kwon 2002). Also, Gu and Wang (2005) argue that information complexity may vary by the regulatory environment. Specifically, less complex information is related to firms within Health Care sector, e.g., biotech and pharmaceutical firms and firms manufacturing equipment used in medical treatment, due to the highly stringent and comprehensive regulations in the approval process of new drugs and new medical equipment. The transparency in the innovation process thus improves sell-side analysts' abilities in making valuable stock recommendations within Health Care sector.

\subsection{Bootstrapping simulations}

Our empirical results in Sects. 4.1 and 4.2 not only provide important evidence to supplement the financial literature, but also have significant implications for market participants. A natural question to ask is whether the reported abnormal returns are as a result of sellside analysts' skill or their luck (Fama 1998; Barber et al. 2001). To address this concern, we develop a time-series bootstrapping simulation method to distinguish sell-side analysts' luck from their skill. In this subsection, our simulated results mirror the three main parts of our empirical results. We focus on presenting the distribution of the $t$-statistics of the abnormal returns rather than the actual abnormal returns, as the $t$-statistic scales the abnormal return by its standard errors and thus has superior statistical properties (see, Fama and French 2010). Specifically, we compare the values of the $t$-statistics at selected percentiles of cumulative distribution function (CDF) of the actual $t$-statistics with the averages

\footnotetext{
13 In general, investors are more likely to purchase stocks following positive recommendations, as it is more expensive to short sell (see, Irvine 2004; Jackson 2005; Mehran and Stulz 2007). As a result, in order to benefit from more trading, brokerage houses could make positively biased recommendations for stocks that actually do not have real investment value. By acting this way in the long term, brokerage houses and their analysts will lose their credibility as investors tend to discount the value of positive recommendations, causing long signals to be less valuable.
} 
Table 4 Percentiles of $t$-statistics for actual and simulated abnormal returns under the Fama and French (2015) five-factor model, using the whole sample of UK sell-side analyst recommendation revisions

\begin{tabular}{|c|c|c|c|c|c|c|}
\hline \multirow[t]{2}{*}{$\%$} & \multicolumn{3}{|c|}{ Upgrade portfolio } & \multicolumn{3}{|c|}{ Downgrade portfolio } \\
\hline & $\begin{array}{l}\text { Simulated } \\
t \text {-stat }\end{array}$ & $\begin{array}{l}\text { Actual } \\
t \text {-stat }\end{array}$ & $\begin{array}{l}\% \text { (simulated } \\
<\text { actual) }\end{array}$ & $\begin{array}{l}\text { Simulated } \\
t \text {-stat }\end{array}$ & $\begin{array}{l}\text { Actual } \\
t \text {-stat }\end{array}$ & $\begin{array}{l}\% \text { (simulated } \\
<\text { actual) }\end{array}$ \\
\hline \multicolumn{7}{|c|}{ Panel A: abnormal gross returns } \\
\hline 1 & -2.47 & -3.27 & 1.93 & -2.76 & -3.11 & 0.16 \\
\hline 2 & -2.06 & -2.85 & 2.24 & -2.35 & -2.77 & 0.31 \\
\hline 3 & -1.87 & -2.62 & 2.93 & -2.08 & -2.51 & 0.71 \\
\hline 4 & -1.75 & -2.46 & 2.94 & -1.93 & -2.35 & 0.70 \\
\hline 5 & -1.64 & -2.34 & 3.02 & -1.78 & -2.21 & 1.39 \\
\hline 10 & -1.27 & -1.88 & 3.24 & -1.35 & -1.81 & 1.69 \\
\hline 20 & -0.83 & -1.37 & 6.85 & -0.87 & -1.27 & 2.22 \\
\hline 30 & -0.52 & -1.01 & 9.88 & -0.50 & -0.85 & 3.61 \\
\hline 40 & -0.25 & -0.67 & 14.45 & -0.21 & -0.51 & 5.46 \\
\hline 50 & -0.01 & -0.41 & 18.62 & 0.05 & -0.20 & 8.98 \\
\hline 60 & 0.24 & -0.15 & 23.35 & 0.26 & 0.11 & 12.17 \\
\hline 70 & 0.50 & 0.14 & 30.80 & 0.45 & 0.37 & 15.17 \\
\hline 80 & 0.81 & 0.53 & 36.74 & 0.65 & 0.64 & 28.70 \\
\hline 90 & 1.25 & 1.01 & 37.04 & 0.87 & 0.95 & 57.47 \\
\hline 95 & 1.61 & 1.42 & 39.58 & 1.07 & 1.23 & 69.75 \\
\hline 96 & 1.72 & 1.53 & 40.82 & 1.13 & 1.35 & 77.19 \\
\hline 97 & 1.84 & 1.67 & 41.28 & 1.23 & 1.48 & 85.27 \\
\hline 98 & 2.02 & 1.82 & 42.42 & 1.38 & 1.78 & 92.63 \\
\hline 99 & 2.32 & 1.95 & 43.56 & 1.79 & 1.92 & 95.30 \\
\hline \multicolumn{7}{|c|}{ Panel B: abnormal net returns } \\
\hline 1 & -2.97 & -3.71 & 0.03 & -0.94 & -1.22 & 0.06 \\
\hline 2 & -2.56 & -3.32 & 0.04 & -0.75 & -1.04 & 0.11 \\
\hline 3 & -2.37 & -2.98 & 0.05 & -0.65 & -0.95 & 0.27 \\
\hline 4 & -2.25 & -2.81 & 0.06 & -0.58 & -0.90 & 0.27 \\
\hline 5 & -2.14 & -2.67 & 0.06 & -0.52 & -0.85 & 0.52 \\
\hline 10 & -1.77 & -2.18 & 0.07 & -0.32 & -0.67 & 0.64 \\
\hline 20 & -1.33 & -1.73 & 0.08 & -0.08 & -0.41 & 0.83 \\
\hline 30 & -1.02 & -1.46 & 0.12 & 0.10 & -0.19 & 1.37 \\
\hline 40 & -0.75 & -1.25 & 0.30 & 0.26 & -0.01 & 2.07 \\
\hline 50 & -0.53 & -1.04 & 0.69 & 0.40 & 0.14 & 3.40 \\
\hline 60 & -0.33 & -0.85 & 2.80 & 0.52 & 0.28 & 4.60 \\
\hline 70 & -0.13 & -0.62 & 3.26 & 0.65 & 0.43 & 5.73 \\
\hline 80 & 0.11 & -0.37 & 5.60 & 0.78 & 0.58 & 10.85 \\
\hline 90 & 0.55 & -0.03 & 9.56 & 0.97 & 0.75 & 21.72 \\
\hline 95 & 0.98 & 0.03 & 12.54 & 1.15 & 0.87 & 26.36 \\
\hline 96 & 1.12 & 0.12 & 24.73 & 1.21 & 0.91 & 29.17 \\
\hline 97 & 1.30 & 0.22 & 27.06 & 1.28 & 0.96 & 36.09 \\
\hline 98 & 1.52 & 0.38 & 31.23 & 1.45 & 1.05 & 37.63 \\
\hline 99 & 1.82 & 0.64 & 35.35 & 1.79 & 1.13 & 38.96 \\
\hline
\end{tabular}


Table 4 (continued)

This table presents the values of $t$-statistics at selected percentiles (\%) of the distribution of $t$-statistics of the actual and simulated abnormal returns, as well as the percentage of the 5000 simulation runs that produce lower values of $t$-statistics at the selected percentiles than those actual abnormal returns (\% simulated < actual) for the upgrade and downgrade portfolios, using the whole sample of UK analyst recommendation revisions from January 1996 to June 2013. The abnormal gross return is estimated as the intercept term derived from the Fama and French (2015) five-factor model. The abnormal net return is calculated as the abnormal gross return less the estimated single-trip transaction costs for purchasing stocks at $0.75 \%$ and for short selling those at $1.5 \%$, multiplied by the corresponding average daily portfolio turnover

of the 5000 simulated $t$-statistics at the same percentiles. If the actual $t$-statistics is higher than $95 \%$ of the 5000 simulated $t$-statistics, we reject the null hypothesis that the abnormal return is due to random chance (sell-side analysts' luck) at the $95 \%$ confidence level and vice versa.

\subsubsection{Simulated results based on the whole sample}

Table 4 shows the CDFs of the actual $t$-statistics of the abnormal returns (both gross and net of transaction costs) and the average of the simulated CDFs for the upgrade and downgrade portfolios, based on the whole sample. The left side of Panel A shows that for the upgrade portfolio, the actual $t$-statistics of the abnormal gross returns are always smaller than the corresponding average values from the simulations for all percentiles. For example, the left tail 5th and 10th percentiles of the actual $t$-statistics are -2.34 and -1.88 , respectively, smaller than the corresponding average values of -1.64 and -1.27 from the simulations. Similarly, the right tail 90th and 95th percentiles of the actual $t$-statistics are 1.01 and 1.42 , respectively, smaller than the average values of 1.25 and 1.61 from the simulations. The simulated results clearly suggest sell-side analysts' lack of skill in making valuable upward revisions for stocks that can generate significantly positive abnormal returns (even before transaction costs). It is not surprising that, in the left side of Panel B, for the upgrade portfolio, the actual $t$-statistics of the abnormal net returns are far below the average values from the simulations for all percentiles, again confirming that sell-side analysts do not possess sufficient skill in making valuable upward revisions in any period of time. Figure $6 \mathrm{a}, \mathrm{b}$ illustrates the CDFs of the actual $t$-statistics of the abnormal gross (net) returns and the corresponding average simulated CDFs for the upgrade portfolio.

The right side of Panel A shows that for the downgrade portfolio, the left tail percentiles of the actual $t$-statistics of the abnormal gross returns are far below the corresponding average values from the simulations. For example, the 5 th and 10 th percentiles of the actual $t$-statistics are -2.21 and -1.81 , respectively, much lower than the average values of -1.78 and -1.35 from the simulations. In contrast, the right tail percentiles of the actual $t$-statistics suggest that sell-side analysts have certain skill in making valuable downward revisions over some periods of time (at least before transaction costs). For example, the 90th and 95th percentiles of the actual $t$-statistics are 0.95 and 1.23, respectively, higher than the average values of 0.87 and 1.07 from the simulations. However, the observed superior skill does not show up more generally in the abnormal net returns as they are absorbed by transaction costs. Specifically, the right side of Panel B shows that for the downgrade portfolio, the actual $t$-statistics of the abnormal net returns are always smaller than the corresponding average values from the simulations for all percentiles, suggesting sell-side analysts' lack of enough skill in making valuable downward revisions for stocks that can generate significant abnormal returns to cover the size of transaction costs in any period of 

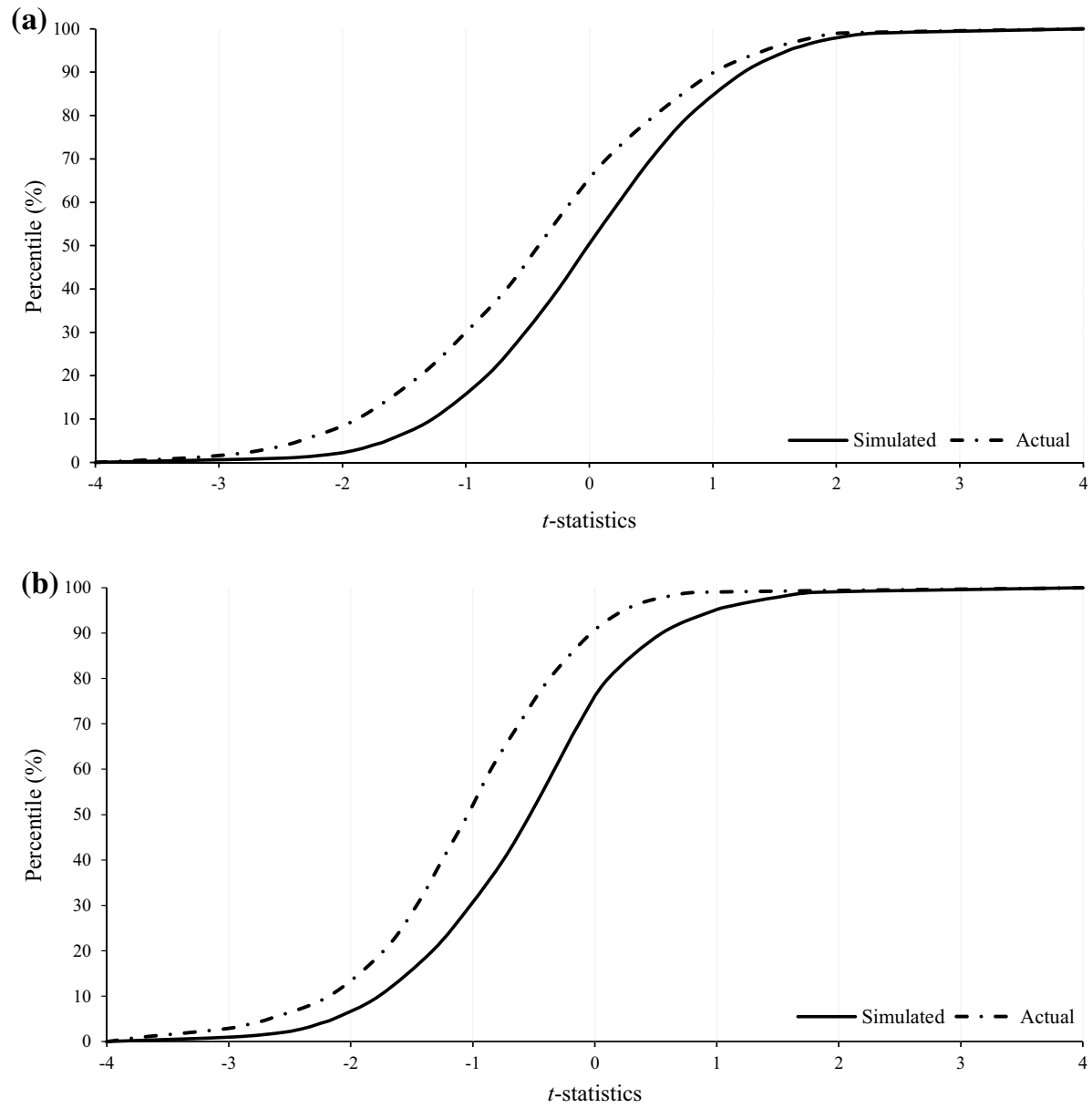

Fig. 6 Simulated and actual cumulative density function (CDF) of $t$-statistics for the abnormal a gross returns and b net returns to the upgrade portfolio, under the Fama and French (2015) five-factor model, using the whole sample

time. Figure $7 \mathrm{a}, \mathrm{b}$ illustrates the CDFs of the actual $t$-statistics of the abnormal gross (net) returns and the corresponding average simulated CDFs for the downgrade portfolio.

\subsubsection{Simulated results based on the subsample made by the top 5 brokerage houses}

We turn now to simulations that use the subsample of analyst recommendation revisions made by the top 5 brokerage houses. Table 5 shows that our subsample simulated results are qualitatively similar to those based on the whole sample, as shown in Table 4, confirming that the reputation of brokerage houses does not matter. That is, on average, even sell-side analysts working for high-ranking brokerage houses have no enough skill to make valuable upward or downward revisions for stocks that can produce abnormal returns to offset the size of transaction costs in any period of time. 


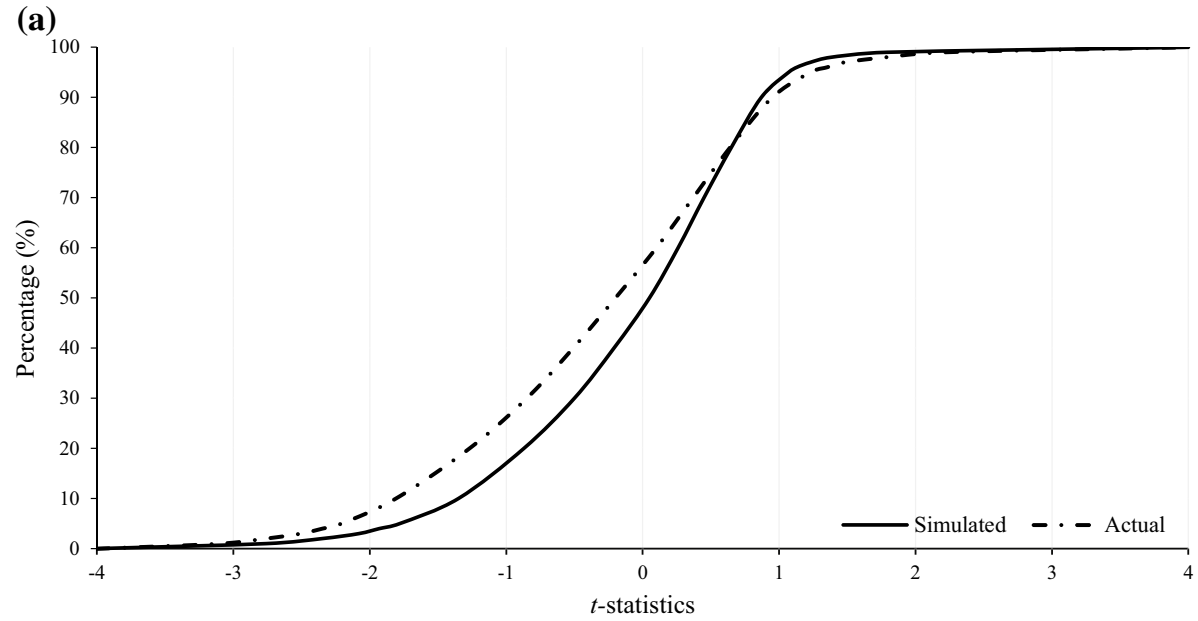

(b)

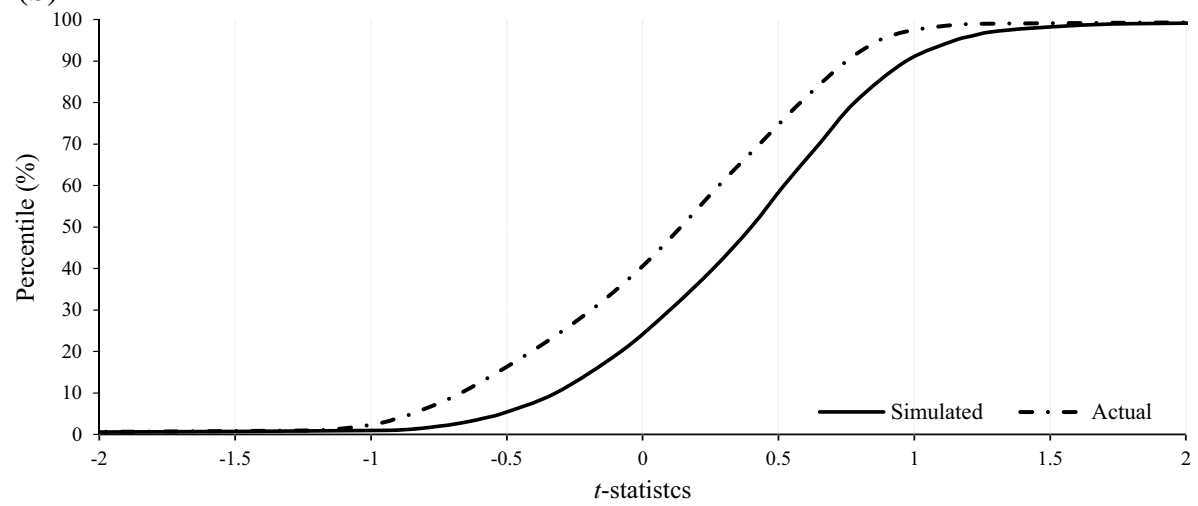

Fig. 7 Simulated and actual cumulative density function (CDF) of $t$-statistics for the abnormal a gross returns and b net returns to the downgrade portfolio, under the Fama and French (2015) five-factor model, using the whole sample

\subsubsection{Simulated results within two high-tech industry sectors}

Finally, our early results in Fig. 5a, b imply that it is likely for investors to make profits after transaction costs, by short selling stocks with downward revisions, within two hightech industry sectors, i.e., Health Care (ICB 45) and Technology (ICB 95) sectors, respectively. Table 6 reports the CDFs of the actual $t$-statistics of the abnormal net returns and the average of the simulated CDFs for the upgrade and downgrade portfolios, within the two high-tech industry sectors. ${ }^{14}$ Specifically, the left side of Panels A and B of Table 6 shows

\footnotetext{
${ }^{14}$ We also conduct bootstrapping simulations within other industry sectors, showing that sell-side analysts do not possess sufficient skill in making valuable upward or downward revisions over the whole sample period, the results of which are not reported for the sake of brevity, but are available on request.
} 
Table 5 Percentiles of $t$-statistics for actual and simulated abnormal returns under the Fama and French (2015) five-factor model, using the subsample of UK sell-side analyst recommendation revisions made by the top 5 brokerage houses

\begin{tabular}{|c|c|c|c|c|c|c|}
\hline \multirow[t]{2}{*}{$\%$} & \multicolumn{3}{|c|}{ Upgrade portfolio } & \multicolumn{3}{|c|}{ Downgrade portfolio } \\
\hline & $\begin{array}{l}\text { Simulated } \\
t \text {-stat }\end{array}$ & $\begin{array}{l}\text { Actual } \\
t \text {-stat }\end{array}$ & $\begin{array}{l}\% \text { (simulated } \\
<\text { actual) }\end{array}$ & $\begin{array}{l}\text { Simulated } \\
t \text {-stat }\end{array}$ & $\begin{array}{l}\text { Actual } \\
t \text {-stat }\end{array}$ & $\begin{array}{l}\% \text { (simulated } \\
<\text { actual) }\end{array}$ \\
\hline \multicolumn{7}{|c|}{ Panel A: abnormal gross returns } \\
\hline 1 & -2.63 & -3.26 & 1.74 & -2.67 & -3.04 & 0.15 \\
\hline 2 & -2.10 & -2.83 & 2.27 & -2.22 & -2.62 & 0.29 \\
\hline 3 & -1.88 & -2.61 & 2.37 & -1.98 & -2.44 & 0.68 \\
\hline 4 & -1.72 & -2.46 & 2.64 & -1.83 & -2.30 & 0.67 \\
\hline 5 & -1.62 & -2.34 & 2.65 & -1.73 & -2.00 & 1.33 \\
\hline 10 & -1.26 & -1.93 & 3.10 & -1.38 & -1.36 & 1.62 \\
\hline 20 & -0.85 & -1.42 & 6.21 & -0.88 & -1.09 & 2.12 \\
\hline 30 & -0.54 & -1.06 & 9.34 & -0.53 & -0.66 & 3.47 \\
\hline 40 & -0.26 & -0.74 & 10.93 & -0.21 & -0.25 & 5.25 \\
\hline 50 & -0.01 & -0.48 & 13.42 & 0.05 & 0.12 & 8.65 \\
\hline 60 & 0.24 & -0.20 & 17.05 & 0.30 & 0.45 & 11.74 \\
\hline 70 & 0.52 & 0.11 & 22.49 & 0.47 & 0.65 & 14.66 \\
\hline 80 & 0.85 & 0.46 & 26.53 & 0.69 & 1.03 & 27.78 \\
\hline 90 & 1.27 & 0.98 & 31.69 & 0.99 & 1.47 & 55.72 \\
\hline 95 & 1.59 & 1.40 & 34.39 & 1.25 & 1.62 & 67.74 \\
\hline 96 & 1.70 & 1.52 & 35.29 & 1.34 & 1.75 & 75.09 \\
\hline 97 & 1.84 & 1.66 & 36.30 & 1.48 & 1.78 & 83.10 \\
\hline 98 & 2.11 & 1.88 & 37.54 & 1.67 & 1.88 & 92.33 \\
\hline 99 & 2.64 & 1.92 & 38.27 & 1.88 & 1.94 & 95.32 \\
\hline \multicolumn{7}{|c|}{ Panel B: abnormal net returns } \\
\hline 1 & -2.70 & -3.74 & 0.02 & -1.21 & -1.40 & 0.06 \\
\hline 2 & -2.16 & -3.35 & 0.04 & -0.85 & -1.31 & 0.11 \\
\hline 3 & -1.94 & -3.12 & 0.04 & -0.71 & -1.08 & 0.27 \\
\hline 4 & -1.77 & -2.98 & 0.05 & -0.66 & -0.94 & 0.26 \\
\hline 5 & -1.66 & -2.85 & 0.05 & -0.55 & -0.84 & 0.51 \\
\hline 10 & -1.29 & -1.89 & 0.06 & -0.39 & -0.80 & 0.62 \\
\hline 20 & -0.87 & -1.50 & 0.08 & -0.08 & -0.76 & 0.82 \\
\hline 30 & -0.55 & -1.40 & 0.09 & 0.03 & -0.52 & 1.34 \\
\hline 40 & -0.27 & -1.05 & 0.19 & 0.22 & -0.30 & 2.04 \\
\hline 50 & -0.01 & -0.80 & 0.50 & 0.46 & -0.07 & 3.35 \\
\hline 60 & 0.25 & -0.67 & 2.14 & 0.54 & 0.11 & 4.55 \\
\hline 70 & 0.53 & -0.47 & 2.78 & 0.79 & 0.26 & 5.68 \\
\hline 80 & 0.87 & -0.24 & 4.51 & 0.91 & 0.48 & 10.78 \\
\hline 90 & 1.30 & -0.02 & 8.18 & 1.03 & 0.57 & 21.65 \\
\hline 95 & 1.63 & 0.03 & 10.02 & 1.28 & 0.80 & 26.33 \\
\hline 96 & 1.74 & 0.11 & 17.03 & 1.37 & 0.86 & 29.20 \\
\hline 97 & 1.89 & 0.26 & 21.81 & 1.52 & 0.93 & 36.21 \\
\hline 98 & 1.93 & 0.36 & 25.60 & 1.62 & 1.12 & 37.85 \\
\hline 99 & 1.95 & 0.71 & 28.15 & 1.82 & 1.31 & 39.27 \\
\hline
\end{tabular}


Table 5 (continued)

This table presents the values of $t$-statistics at selected percentiles (\%) of the distribution of $t$-statistics of the actual and simulated abnormal returns, as well as the percentage of the 5000 simulation runs that produce lower values of $t$-statistics at the selected percentiles than those actual abnormal returns (\% simulated < actual) for the upgrade and downgrade portfolios, using the subsample of UK sell-side analyst recommendation revisions made by the top 5 brokerage houses from January 1996 to June 2013. The abnormal gross return is estimated as the intercept term derived from the Fama and French (2015) five-factor model. The abnormal net return is calculated as the abnormal gross return less the estimated single-trip transaction costs for purchasing stocks at $0.75 \%$ and for short selling those at $1.5 \%$, multiplied by the corresponding average daily portfolio turnover. The top 5 brokerage houses are identified by their 3-year moving average $(t-3, t-2, t-1)$ of positions on the annual All-Europe Research Team published by Institutional Investor (see "Appendix 1")

that, for the upgrade portfolio, the actual $t$-statistics are always smaller than the average values from the simulations for all percentiles within both industry sectors, suggesting sellside analysts' lack of skill in making valuable upward revisions over the whole sample period.

In contrast, for the downgrade portfolio within Health Care sector, the right tails of the CDFs of the actual $t$-statistics suggest that there are superior sell-side analysts who can make valuable downgrades after transaction costs over some periods of time. For example, the right side of Panel A shows that the CDF of the actual $t$-statistics of the abnormal net returns moves to the right tail of the average from the simulations at about the 80th percentile. The 95 th percentile of $t$-statistics averages 0.79 for the simulations, but the actual 95 th percentile of $t$-statistics is higher, 1.24. Similarly, for the downgrade portfolio within Technology sector, the crossover occurs at the higher percentile (around the 70th), suggesting that sell-side analysts do possess sufficient skill in making valuable downgrades for stocks with high-tech related characteristics over some periods of time, even after transaction costs. Figures $8 \mathrm{a}, \mathrm{b}$ illustrate the CDFs of the actual $t$-statistics of the abnormal net returns and the corresponding average simulated CDFs for the downgrade portfolio, within the industry sector of Health Care (Technology).

\section{Conclusions}

The purpose of this inquiry is to conduct an in-depth investigation into the investment value of sell-side analyst recommendation revisions in the UK from January 1995 to June 2013, using a uniquely insightful database that has never been examined before. We take an investor-oriented, calendar-time perspective, to assess the time-varying performance of the upgrade and downgrade portfolios. Our empirical investigation shows that, on average, sell-side analysts' upward revisions are valueless over the whole sample period; it is likely for investors to make profits by short selling stocks with downward revisions (before transaction costs) over some periods of time, while these profits disappear after transaction costs. Our results do not alter when we construct two alternative upgrade and downgrade portfolios exclusively using a subsample of analyst recommendation revisions made by the top 5 brokerage houses. This suggests that the reputation of brokerage houses does not play an important role in making valuable analyst recommendation revisions in the 
Table 6 Percentiles of $t$-statistics for actual and simulated abnormal net returns under the Fama and French (2015) five-factor model, within two industry sectors of Health Care (ICB 45) and Technology (ICB 95)

\begin{tabular}{|c|c|c|c|c|c|c|}
\hline \multirow[t]{2}{*}{$\%$} & \multicolumn{3}{|c|}{ Upgrade portfolio } & \multicolumn{3}{|c|}{ Downgrade portfolio } \\
\hline & $\begin{array}{l}\text { Simulated } \\
t \text {-stat }\end{array}$ & $\begin{array}{l}\text { Actual } \\
t \text {-stat }\end{array}$ & $\begin{array}{l}\% \text { (simulated } \\
<\text { actual) }\end{array}$ & $\begin{array}{l}\text { Simulated } \\
t \text {-stat }\end{array}$ & $\begin{array}{l}\text { Actual } \\
t \text {-stat }\end{array}$ & $\begin{array}{l}\% \text { (simulated } \\
<\text { actual) }\end{array}$ \\
\hline \multicolumn{7}{|c|}{ Panel A: abnormal net returns within Health Care (ICB 45) sector } \\
\hline 1 & -2.49 & -3.69 & 0.03 & -2.68 & -3.41 & 3.19 \\
\hline 2 & -2.17 & -3.36 & 0.04 & -2.23 & -2.98 & 3.01 \\
\hline 3 & -1.98 & -3.13 & 0.06 & -1.95 & -2.72 & 3.42 \\
\hline 4 & -1.84 & -3.00 & 0.06 & -1.78 & -2.51 & 4.16 \\
\hline 5 & -1.73 & -2.87 & 0.06 & -1.68 & -2.39 & 5.19 \\
\hline 10 & -1.35 & -2.54 & 0.06 & -1.38 & -1.89 & 8.53 \\
\hline 20 & -0.88 & -2.01 & 0.07 & -1.03 & -1.45 & 11.69 \\
\hline 30 & -0.55 & -1.58 & 0.09 & -0.77 & -1.15 & 21.29 \\
\hline 40 & -0.26 & -1.20 & 0.11 & -0.57 & -0.93 & 27.31 \\
\hline 50 & 0.01 & -0.87 & 0.12 & -0.41 & -0.71 & 35.14 \\
\hline 60 & 0.27 & -0.51 & 0.17 & -0.26 & -0.51 & 43.22 \\
\hline 70 & 0.57 & -0.18 & 0.21 & -0.11 & -0.28 & 54.26 \\
\hline 80 & 0.91 & 0.19 & 0.39 & 0.08 & 0.01 & 60.28 \\
\hline 90 & 1.38 & 0.88 & 6.10 & 0.41 & 0.56 & 74.62 \\
\hline 95 & 1.77 & 1.35 & 12.08 & 0.79 & 1.24 & 80.30 \\
\hline 96 & 1.89 & 1.49 & 14.54 & 0.93 & 1.38 & 84.60 \\
\hline 97 & 2.03 & 1.61 & 16.00 & 1.10 & 1.61 & 87.67 \\
\hline 98 & 2.22 & 1.81 & 24.02 & 1.36 & 1.89 & 93.82 \\
\hline 99 & 2.52 & 1.87 & 34.64 & 1.81 & 1.92 & 95.46 \\
\hline \multicolumn{7}{|c|}{ Panel B: abnormal net returns within Technology (ICB 95) sector } \\
\hline 1 & -3.07 & -3.73 & 0.06 & -2.69 & -3.30 & 1.74 \\
\hline 2 & -2.50 & -3.42 & 0.07 & -2.25 & -2.64 & 4.36 \\
\hline 3 & -2.20 & -3.17 & 0.08 & -1.98 & -2.39 & 4.55 \\
\hline 4 & -2.05 & -2.90 & 0.10 & -1.81 & -2.22 & 6.46 \\
\hline 5 & -1.93 & -2.71 & 0.10 & -1.69 & -2.11 & 7.12 \\
\hline 10 & -1.48 & -2.17 & 0.11 & -1.39 & -1.73 & 7.70 \\
\hline 20 & -0.99 & -1.69 & 0.13 & -1.15 & -1.35 & 8.77 \\
\hline 30 & -0.62 & -1.32 & 0.16 & -1.06 & -1.20 & 9.65 \\
\hline 40 & -0.30 & -1.03 & 0.22 & -1.02 & -1.12 & 14.12 \\
\hline 50 & -0.01 & -0.75 & 0.25 & -1.01 & -1.07 & 16.48 \\
\hline 60 & 0.29 & -0.46 & 0.30 & -0.99 & -1.03 & 25.75 \\
\hline 70 & 0.57 & -0.13 & 0.31 & -0.98 & -0.98 & 54.93 \\
\hline 80 & 0.91 & 0.29 & 0.62 & -0.95 & -0.88 & 56.24 \\
\hline 90 & 1.38 & 0.90 & 5.02 & -0.85 & -0.73 & 66.68 \\
\hline 95 & 1.79 & 1.33 & 8.14 & -0.73 & -0.60 & 73.57 \\
\hline 96 & 1.90 & 1.44 & 10.40 & -0.69 & -0.55 & 78.85 \\
\hline 97 & 2.04 & 1.62 & 12.31 & -0.61 & -0.47 & 85.59 \\
\hline 98 & 2.24 & 1.82 & 14.79 & -0.47 & -0.32 & 92.15 \\
\hline 99 & 2.75 & 1.84 & 24.27 & -0.15 & -0.05 & 96.24 \\
\hline
\end{tabular}


Table 6 (continued)

This table presents the values of $t$-statistics at selected percentiles (\%) of the distribution of $t$-statistics of the actual and simulated abnormal returns, as well as the percentage of the 5000 simulation runs that produce lower values of $t$-statistics at the selected percentiles than those actual abnormal returns for the upgrade and downgrade portfolios, using the subsample of UK sell-side analyst recommendation revisions within two high-tech industry sectors, i.e., Health Care (ICB 45 in Panel A) and Technology (ICB 95 in Panel B) sectors, identified by the two-digit ICB codes (see "Appendix 2"), from January 1996 to June 2013. The abnormal net return is calculated as the abnormal gross return, which is estimated as the intercept term derived from the Fama and French (2015) five-factor model, less the estimated single-trip transaction costs for purchasing stocks at $0.75 \%$ and for short selling those at $1.5 \%$, multiplied by the corresponding average daily portfolio turnover

(a)

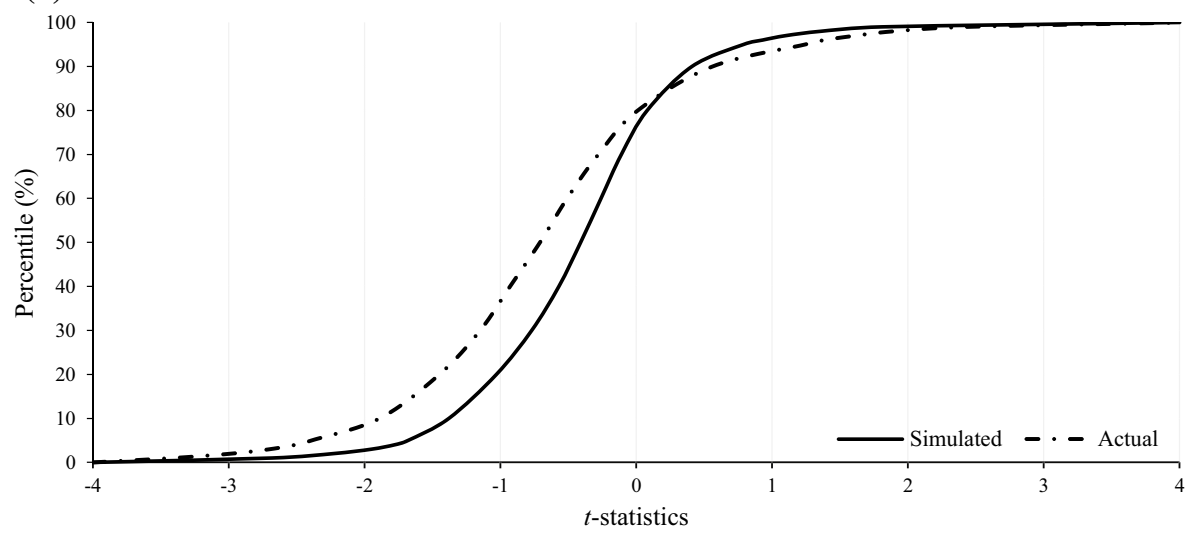

(b)

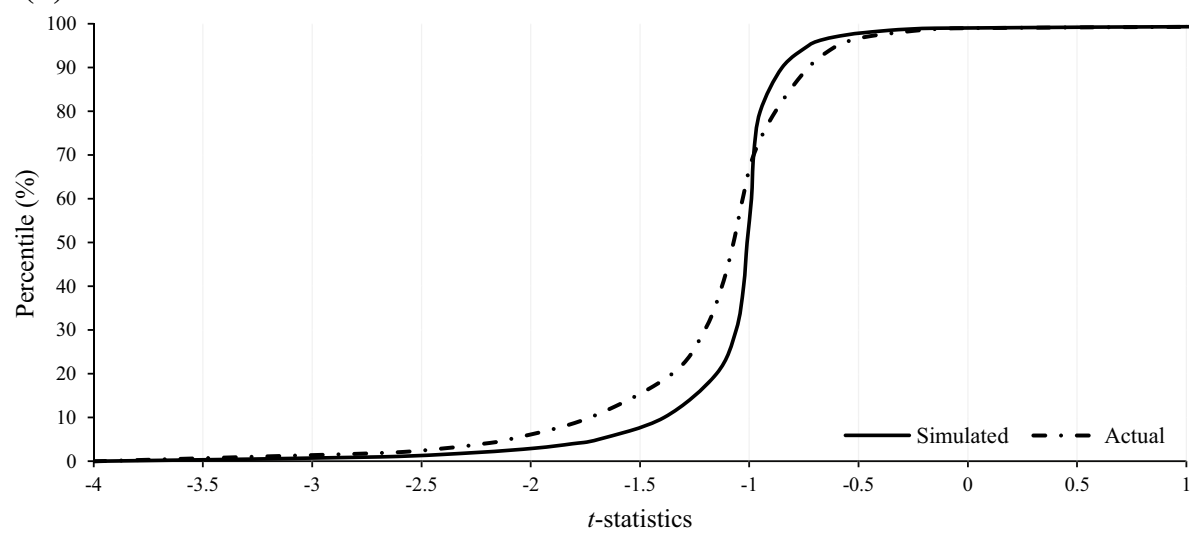

Fig. 8 Simulated and actual cumulative density function (CDF) of $t$-statistics for the abnormal net returns to the downgrade portfolio, under the Fama and French (2015) five-factor model, within a Health Care (ICB 45) sector and b Technology (ICB 95) sector 
UK, inconsistent with that reported in the US. One possible explanation on the discrepancy could be that the annual All-European Research Team published by Institutional Investor has less influence on UK sell-side analysts' career concern, compared with the influence of its US counterpart. Further research might focus on the development of more appropriate proxies for the reputation of brokerage houses and sell-side analysts in the UK (see, e.g., Nolte et al. 2014).

However, our industry-based analysis shows that, within two high-tech industry sectors, i.e., Health Care (ICB 45) and Technology (ICB 95) sectors, the downgrade portfolio generates significantly negative abnormal net returns in several periods of time. These significantly negative abnormal net returns suggest the importance of controlling for industry in sell-side analyst research. From an investor's perspective, it is likely to make large enough profits to cover the size of transaction costs by short selling stocks with downward revisions with high-tech related characteristics over some periods of time.

Our time-series bootstrapping simulations confirm that, on average, (1) the observed insignificantly positive abnormal returns (both gross and net of transaction costs) to the upgrade portfolio could be attributed to sell-side analysts' lack of skill in making valuable upward revisions, rather than their bad luck; and (2) sell-side analysts have certain skill in making valuable downward revisions over some periods of time (at least before transaction costs), though such skill is not sufficient to cover the size of transaction costs. More importantly, our simulated results confirm that sell-side analysts do possess superior skill in making valuable downward revisions for stocks with high-tech related characteristics, even after transaction costs are taken into account.

Finally, it is worth mentioning that there is some slight differences between the investment value and profitability of sell-side analyst recommendations. ${ }^{15}$ On the one hand, analyst recommendations could be worthless, but the portfolio might be profitable. For example, Green (2006) reports that early access to stock recommendations provides investors with incremental investment value, which could be attributed to the existence of momentum traders in the market (Hong and Stein 1999). These momentum traders have a tendency to exchange aggressively and deviate a stock's price beyond its fundamental value, thus leading to a market overreaction in the short term. On the other hand, analyst recommendations are in fact valuable, but the portfolio might end up not being profitable, probably due to the crowd effect when the information is widely and publicly broadcast. According to Hong and Stein (1999), the market firstly underreacts to the release of analyst recommendations, as news watchers tend to react to information with a delay. The initial underreaction is generally followed by overreaction, since investors may chase fad, which drives stock prices overshoot their long-term equilibrium, and eventually causes the portfolio not profitable in the long term. In this manner, the key implication of the Hong and Stein (1999) model on sell-side analyst research is the speed of reaction to stock recommendations (Green 2006; Jegadeesh and Kim 2006), which could be left for future research.

Acknowledgements The authors wish to thank for the helpful comments and suggestions from two anonymous reviewers, the editor-in-chief (Cheng-Few Lee), Carol O. Alexander, Stephen J. Brown, Thierry Foucault, Barbara S. Petitt, Richard J. Taffler, Brian M. Lucey, and seminar participants at Newcastle University Business School and Lincoln International Business School. A special thank-you goes to Shanta S.K. Davie for her time and efforts taken in the revision process. Su also thanks financial supports from Newcastle University Business School under the School Pump Priming/Research Fund 2012/13, the School Impact Fund 2015/16, and the School Strategic Fund 2017/18. All remaining errors and omissions are our own.

\footnotetext{
15 We thank an anonymous reviewer for pointing out the difference between the investment value and profitability of sell-side analyst recommendations.
} 
Open Access This article is distributed under the terms of the Creative Commons Attribution 4.0 International License (http://creativecommons.org/licenses/by/4.0/), which permits unrestricted use, distribution, and reproduction in any medium, provided you give appropriate credit to the original author(s) and the source, provide a link to the Creative Commons license, and indicate if changes were made.

\section{Appendix 1: The top 5 brokerage houses}

\begin{tabular}{|c|c|c|c|}
\hline Ranking & Brokerage houses & Ranking & Brokerage houses \\
\hline 1996 & & 1997 & \\
\hline 1 & SBC Warburg Securities $(1,1,1)$ & 1 & SBC Warburg $(1,1,1)$ \\
\hline 2 & James Capel and Co. $(2,2,2)$ & 2 & James Capel and Co. $(2,2,2)$ \\
\hline 3 & Barclays de Zoete Wedd (BZW) $(4,3,3)$ & 3 & BZW $(3,3,6)$ \\
\hline 4 & NatWest Securities $(5,5,5)$ & 4 & NatWest Securities $(5,5,5)$ \\
\hline 5 & UBS $(2,6,8)$ & 5 & UBS $(6,8,3)$ \\
\hline 1998 & & 1999 & \\
\hline 1 & SBC Warburg Dillion Read $(1,1,1)$ & 1 & Warburg Dillion Read $(1,1,1)$ \\
\hline 2 & HSBC James Capel $(2,2,5)$ & 2 & $\operatorname{UBS}(3,2,3)$ \\
\hline 3 & UBS $(8,3,2)$ & 3 & Merrill Lynch $(4,3,2)$ \\
\hline 4 & NatWest Securities $(5,5,4)$ & 4 & NatWest Securities $(5,4,4)$ \\
\hline 5 & $\operatorname{BZM}(3,6,6)$ & 5 & HSBC James Capel $(2,5,9)$ \\
\hline 2000 & & 2001 & \\
\hline 1 & Warburg Dillion Read $(1,1,2)$ & 1 & Merrill Lynch $(2,1,1)$ \\
\hline 2 & Merrill Lynch $(3,2,1)$ & 2 & Warburg Dillon Read $(1,2,3)$ \\
\hline 3 & Goldman Sachs International $(7,5,4)$ & 3 & Goldman Sachs International $(5,4,6)$ \\
\hline 4 & HSBC Securities $(5,9,8)$ & 4 & Morgan Stanley Dean Witter $(11,3,2)$ \\
\hline 5 & Morgan Stanley Dean Witter $(9,11,3)$ & 5 & $\begin{array}{l}\text { Credit Suisse First Boston }(12,6,4) \\
\text { Deutsche Bank }(9,8,5)\end{array}$ \\
\hline 2002 & & 2003 & \\
\hline 1 & Merrill Lynch $(1,1,2)$ & 1 & Credit Suisse First Boston $(4,1,2)$ \\
\hline 2 & UBS Warburg $(2,3,4)$ & 2 & UBS Warburg $(3,4,1)$ \\
\hline 3 & Morgan Stanley Dean Witter $(3,2,5)$ & 2 & Merrill Lynch $(1,2,5)$ \\
\hline 4 & Credit Suisse First Boston $(6,4,1)$ & 4 & Deutsche Bank $(5,3,3)$ \\
\hline 5 & Deutsche Bank $(8,5,3)$ & 5 & Morgan Stanley $(2,5,6)$ \\
\hline 2004 & & 2005 & \\
\hline 1 & UBS Warburg $(4,1,1)$ & 1 & UBS $(1,1,1)$ \\
\hline 2 & Credit Suisse First Boston $(1,2,4)$ & 2 & Smith Barney Citigroup $(4,2,2)$ \\
\hline 3 & Deutsche Bank $(3,3,3)$ & 3 & Credit Suisse First Boston $(2,4,3)$ \\
\hline 4 & $\begin{array}{l}\text { Citigroup/Schroder Salomon Smith } \\
\text { Barney }(6,4,2)\end{array}$ & 4 & Deutsche Bank $(3,3,5)$ \\
\hline 4 & Merrill Lynch $(2,5,5)$ & 5 & Merrill Lynch $(5,5,3)$ \\
\hline 2006 & & 2007 & \\
\hline 1 & $\operatorname{UBS}(1,1,1)$ & 1 & $\operatorname{UBS}(1,1,1)$ \\
\hline 2 & Smith Barney Citigroup $(2,2,4)$ & 2 & Citigroup $(2,4,2)$ \\
\hline 3 & Deutsche Bank $(3,5,2)$ & 3 & Deutsche Bank $(5,2,3)$ \\
\hline 4 & Merrill Lynch $(5,3,3)$ & 4 & Merrill Lynch $(3,3,5)$ \\
\hline 5 & Credit Suisse First Boston $(4,3,6)$ & 5 & Credit Suisse $(3,6,5)$ \\
\hline
\end{tabular}




\begin{tabular}{|c|c|c|c|}
\hline Ranking & Brokerage houses & Ranking & Brokerage houses \\
\hline 2008 & & 2009 & \\
\hline 1 & $\operatorname{UBS}(1,1,1)$ & 1 & UBS $(1,1,1)$ \\
\hline 2 & Citigroup $(4,2,2)$ & 2 & Citi Investment Research $(2,2,2)$ \\
\hline 3 & Deutsche Bank $(2,3,5)$ & 3 & Merrill Lynch $(5,3,3)$ \\
\hline 4 & Merrill Lynch $(3,5,3)$ & 4 & Credit Suisse $(5,4,4)$ \\
\hline 5 & Credit Suisse $(6,5,4)$ & 5 & Deutsche Bank $(3,5,7)$ \\
\hline 2010 & & 2011 & \\
\hline 1 & $\operatorname{UBS}(1,1,1)$ & 1 & UBS $(1,1,1)$ \\
\hline 2 & Citi $(2,2,3)$ & 2 & $\begin{array}{l}\text { BofA Merrill Lynch Global Research (3, } \\
\quad 2,5)\end{array}$ \\
\hline 3 & $\begin{array}{l}\text { Bank of America Securities-Merrill } \\
\text { Lynch }(3,3,2)\end{array}$ & 2 & Credit Suisse $(4,5,2)$ \\
\hline 4 & Credit Suisse $(4,4,5)$ & 2 & Citi $(2,3,8)$ \\
\hline 5 & Morgan Stanley $(7,5,5)$ & 5 & J.P. Morgan $(8,4,2)$ \\
\hline 2012 & & 2013 & \\
\hline 1 & UBS $(1,1,2)$ & 1 & UBS $(1,2,2)$ \\
\hline 2 & J.P. Morgan Cazenove $(4,2,4)$ & 2 & Deutsche Bank $(6,1,1)$ \\
\hline 2 & $\begin{array}{l}\text { BofA Merrill Lynch Global Research } \\
\quad(2,5,3)\end{array}$ & 3 & $\begin{array}{l}\text { BofA Merrill Lynch Global Research (5, } \\
\text { 3, 2) }\end{array}$ \\
\hline 4 & Credit Suisse $(5,2,4)$ & 3 & J.P. Morgan Cazenove $(2,4,4)$ \\
\hline 5 & Deutsche Bank $(7,6,1)$ & 5 & Credit Suisse $(2,4,6)$ \\
\hline
\end{tabular}

This appendix provides a list of the top 5 brokerage houses based on their 3-year moving average of positions on the annual All-Europe Research Team published by Institutional Investor from 1996 to 2013. For each brokerage house in each year of $t$, its positions in previous 3 years $(t-3, t-2, t-1)$ are shown in bracket. For example, the ranking of each brokerage house in the calendar year of 1996 is determined based on its average position in the years of 1995, 1994, and 1993

\section{Appendix 2: Distribution of UK analyst recommendation revisions in the upgrade and downgrade portfolios by industry sectors of the covered firms}

\begin{tabular}{|c|c|c|c|c|c|c|c|c|c|}
\hline \multirow{2}{*}{$\begin{array}{l}\text { Two-digit } \\
\text { ICB codes }\end{array}$} & \multirow{2}{*}{$\begin{array}{l}\text { Three-digit } \\
\text { ICB codes }\end{array}$} & \multicolumn{4}{|c|}{ Upgrade portfolio } & \multicolumn{4}{|c|}{ Downgrade portfolio } \\
\hline & & $\begin{array}{l}\text { No. of } \\
\text { covered } \\
\text { firms }\end{array}$ & $\begin{array}{l}\text { No. of } \\
\text { broker- } \\
\text { age } \\
\text { houses }\end{array}$ & $\begin{array}{l}\text { Average } \\
\text { rating }\end{array}$ & $\begin{array}{l}\text { No. of } \\
\text { upward } \\
\text { revi- } \\
\text { sions }\end{array}$ & $\begin{array}{l}\text { No. of } \\
\text { covered } \\
\text { firms }\end{array}$ & $\begin{array}{l}\text { No. of } \\
\text { broker- } \\
\text { age } \\
\text { houses }\end{array}$ & $\begin{array}{l}\text { Average } \\
\text { rating }\end{array}$ & $\begin{array}{l}\text { No. of } \\
\text { down- } \\
\text { ward } \\
\text { revisions }\end{array}$ \\
\hline \multirow[t]{3}{*}{$\begin{array}{l}05 \text { Oil and } \\
\text { Gas }\end{array}$} & $\begin{array}{c}053 \text { Oil and } \\
\text { Gas Pro- } \\
\text { ducers }\end{array}$ & 58 & 55 & $\begin{array}{l}2.21 \\
\quad[1.23]\end{array}$ & 746 & 66 & 59 & $\begin{array}{l}6.10 \\
\quad[3.66]\end{array}$ & 798 \\
\hline & $\begin{array}{l}057 \text { Oil } \\
\text { Equipment, } \\
\text { Services, } \\
\text { and Distri- } \\
\text { bution }\end{array}$ & 18 & 39 & $\begin{array}{l}2.29 \\
\quad[1.27]\end{array}$ & 269 & 18 & 41 & $\begin{array}{l}5.73 \\
\quad[3.44]\end{array}$ & 266 \\
\hline & $\begin{array}{l}\text { 058 Alterna- } \\
\text { tive Energy }\end{array}$ & 8 & 16 & $\begin{array}{l}2.14 \\
\quad[1.14]\end{array}$ & 35 & 5 & 14 & $\begin{array}{l}5.32 \\
{[3.20]}\end{array}$ & 25 \\
\hline
\end{tabular}




\begin{tabular}{|c|c|c|c|c|c|c|c|c|c|}
\hline \multirow{2}{*}{$\begin{array}{l}\text { Two-digit } \\
\text { ICB codes }\end{array}$} & \multirow{2}{*}{$\begin{array}{l}\text { Three-digit } \\
\text { ICB codes }\end{array}$} & \multicolumn{4}{|c|}{ Upgrade portfolio } & \multicolumn{4}{|c|}{ Downgrade portfolio } \\
\hline & & $\begin{array}{l}\text { No. of } \\
\text { covered } \\
\text { firms }\end{array}$ & $\begin{array}{l}\text { No. of } \\
\text { broker- } \\
\text { age } \\
\text { houses }\end{array}$ & $\begin{array}{l}\text { Average } \\
\text { rating }\end{array}$ & $\begin{array}{l}\text { No. of } \\
\text { upward } \\
\text { revi- } \\
\text { sions }\end{array}$ & $\begin{array}{l}\text { No. of } \\
\text { covered } \\
\text { firms }\end{array}$ & $\begin{array}{l}\text { No. of } \\
\text { broker- } \\
\text { age } \\
\text { houses }\end{array}$ & $\begin{array}{l}\text { Average } \\
\text { rating }\end{array}$ & $\begin{array}{l}\text { No. of } \\
\text { down- } \\
\text { ward } \\
\text { revisions }\end{array}$ \\
\hline $\begin{array}{l}13 \text { Chemi- } \\
\text { cals }\end{array}$ & $\begin{array}{l}135 \text { Chemi- } \\
\text { cals }\end{array}$ & 39 & 52 & $\begin{array}{l}2.25 \\
{[1.24]}\end{array}$ & 701 & 40 & 54 & $\begin{array}{l}5.69 \\
{[3.44]}\end{array}$ & 763 \\
\hline \multirow[t]{3}{*}{$\begin{array}{l}17 \text { Basic } \\
\text { Resources }\end{array}$} & $\begin{array}{c}173 \text { Forestry } \\
\text { and Paper }\end{array}$ & 4 & 13 & $\begin{array}{l}2.31 \\
\quad[1.31]\end{array}$ & 32 & 4 & 15 & $\begin{array}{l}6.07 \\
{[3.67]}\end{array}$ & 43 \\
\hline & $\begin{array}{l}175 \text { Industrial } \\
\text { Metals and } \\
\text { Mining }\end{array}$ & 8 & 24 & $\begin{array}{l}2.23 \\
\quad[1.25]\end{array}$ & 53 & 11 & 31 & $\begin{array}{l}6.51 \\
{[3.96]}\end{array}$ & 111 \\
\hline & 177 Mining & 62 & 46 & $\begin{array}{l}2.19 \\
\quad[1.21]\end{array}$ & 536 & 57 & 47 & $\begin{array}{l}5.99 \\
{[3.62]}\end{array}$ & 613 \\
\hline $\begin{array}{l}23 \text { Construc- } \\
\text { tion and } \\
\text { Materials }\end{array}$ & $\begin{array}{l}235 \text { Con- } \\
\text { struction } \\
\text { and Materi- } \\
\text { als }\end{array}$ & 66 & 52 & $\begin{array}{l}2.31 \\
\quad[1.26]\end{array}$ & 929 & 64 & 57 & $\begin{array}{l}5.98 \\
{[3.61]}\end{array}$ & 1022 \\
\hline \multirow[t]{6}{*}{$\begin{array}{c}27 \text { Industrial } \\
\text { Goods and } \\
\text { Services }\end{array}$} & $\begin{array}{l}271 \text { Aero- } \\
\text { space and } \\
\text { Defence }\end{array}$ & 17 & 49 & $\begin{array}{l}2.30 \\
{[1.28]}\end{array}$ & 584 & 17 & 48 & $\begin{array}{l}5.72 \\
{[3.44]}\end{array}$ & 514 \\
\hline & $\begin{array}{r}272 \text { General } \\
\text { Industrials }\end{array}$ & 18 & 44 & $\begin{array}{l}2.23 \\
{[1.25]}\end{array}$ & 400 & 19 & 50 & $\begin{array}{l}5.79 \\
{[3.48]}\end{array}$ & 492 \\
\hline & $\begin{array}{l}273 \text { Elec- } \\
\text { tronic and } \\
\text { Electrical } \\
\text { Equipment }\end{array}$ & 66 & 46 & $\begin{array}{l}2.30 \\
{[1.27]}\end{array}$ & 602 & 73 & 53 & $\begin{array}{l}5.69 \\
{[3.42]}\end{array}$ & 691 \\
\hline & $\begin{array}{l}275 \text { Industrial } \\
\text { Engineer- } \\
\text { ing }\end{array}$ & 77 & 50 & $\begin{array}{l}2.29 \\
{[1.26]}\end{array}$ & 976 & 83 & 57 & $\begin{array}{l}5.67 \\
{[3.41]}\end{array}$ & 1053 \\
\hline & $\begin{array}{l}277 \text { Industrial } \\
\text { Transporta- } \\
\text { tion }\end{array}$ & 39 & 49 & $\begin{array}{l}2.25 \\
{[1.24]}\end{array}$ & 489 & 42 & 54 & $\begin{array}{l}5.87 \\
{[3.55]}\end{array}$ & 596 \\
\hline & $\begin{array}{l}279 \text { Support } \\
\text { Services }\end{array}$ & 221 & 67 & $\begin{array}{l}2.25 \\
{[1.24]}\end{array}$ & 2757 & 236 & 73 & $\begin{array}{l}5.85 \\
{[3.53]}\end{array}$ & 3019 \\
\hline $\begin{array}{l}33 \text { Automo- } \\
\text { biles and } \\
\text { Parts }\end{array}$ & $\begin{array}{l}335 \text { Automo- } \\
\text { biles and } \\
\text { Parts }\end{array}$ & 14 & 34 & $\begin{array}{l}2.28 \\
{[1.26]}\end{array}$ & 184 & 18 & 41 & $\begin{array}{l}5.89 \\
{[3.56]}\end{array}$ & 245 \\
\hline \multirow[t]{2}{*}{$\begin{array}{c}35 \text { Food and } \\
\text { Beverage }\end{array}$} & $\begin{array}{l}353 \text { Bever- } \\
\text { ages }\end{array}$ & 14 & 42 & $\begin{array}{l}2.27 \\
\quad[1.25]\end{array}$ & 293 & 15 & 48 & $\begin{array}{l}6.17 \\
{[3.75]}\end{array}$ & 415 \\
\hline & $\begin{array}{l}357 \text { Food } \\
\text { Producers }\end{array}$ & 46 & 46 & $\begin{array}{l}2.24 \\
\quad[1.25]\end{array}$ & 788 & 52 & 49 & $\begin{array}{l}5.86 \\
{[3.54]}\end{array}$ & 981 \\
\hline \multirow[t]{4}{*}{$\begin{array}{l}37 \text { Personal } \\
\text { and } \\
\text { Household } \\
\text { Goods }\end{array}$} & $\begin{array}{l}372 \text { House- } \\
\text { hold Goods } \\
\text { and Home } \\
\text { Construc- } \\
\text { tion }\end{array}$ & 57 & 52 & $\begin{array}{l}2.33 \\
{[1.26]}\end{array}$ & 962 & 62 & 56 & $\begin{array}{l}5.94 \\
{[3.59]}\end{array}$ & 1105 \\
\hline & $\begin{array}{l}374 \text { Leisure } \\
\text { Goods }\end{array}$ & 16 & 29 & $\begin{array}{l}2.33 \\
\quad[1.25]\end{array}$ & 135 & 18 & 33 & $\begin{array}{l}5.77 \\
{[3.47]}\end{array}$ & 158 \\
\hline & $\begin{array}{l}376 \text { Personal } \\
\text { Goods }\end{array}$ & 39 & 38 & $\begin{array}{l}2.32 \\
\quad[1.24]\end{array}$ & 260 & 46 & 43 & $\begin{array}{l}5.66 \\
{[3.42]}\end{array}$ & 302 \\
\hline & 378 Tobacco & 3 & 18 & $\begin{array}{l}2.09 \\
{[1.15]}\end{array}$ & 94 & 3 & 19 & $\begin{array}{l}5.91 \\
{[3.58]}\end{array}$ & 100 \\
\hline
\end{tabular}




\begin{tabular}{|c|c|c|c|c|c|c|c|c|c|}
\hline \multirow{2}{*}{$\begin{array}{l}\text { Two-digit } \\
\text { ICB codes }\end{array}$} & \multirow{2}{*}{$\begin{array}{l}\text { Three-digit } \\
\text { ICB codes }\end{array}$} & \multicolumn{4}{|c|}{ Upgrade portfolio } & \multicolumn{4}{|c|}{ Downgrade portfolio } \\
\hline & & $\begin{array}{l}\text { No. of } \\
\text { covered } \\
\text { firms }\end{array}$ & $\begin{array}{l}\text { No. of } \\
\text { broker- } \\
\text { age } \\
\text { houses }\end{array}$ & $\begin{array}{l}\text { Average } \\
\text { rating }\end{array}$ & $\begin{array}{l}\text { No. of } \\
\text { upward } \\
\text { revi- } \\
\text { sions }\end{array}$ & $\begin{array}{l}\text { No. of } \\
\text { covered } \\
\text { firms }\end{array}$ & $\begin{array}{l}\text { No. of } \\
\text { broker- } \\
\text { age } \\
\text { houses }\end{array}$ & $\begin{array}{l}\text { Average } \\
\text { rating }\end{array}$ & $\begin{array}{l}\text { No. of } \\
\text { down- } \\
\text { ward } \\
\text { revisions }\end{array}$ \\
\hline \multirow[t]{2}{*}{$\begin{array}{l}45 \text { Health } \\
\text { Care }\end{array}$} & $\begin{array}{l}453 \text { Health } \\
\text { Care Equip- } \\
\text { ment and } \\
\text { Services }\end{array}$ & 39 & 49 & $\begin{array}{l}2.23 \\
{[1.22]}\end{array}$ & 392 & 46 & 52 & $\begin{array}{l}5.72 \\
{[3.44]}\end{array}$ & 480 \\
\hline & $\begin{array}{l}457 \text { Pharma- } \\
\text { ceuticals } \\
\text { and Bio- } \\
\text { technology }\end{array}$ & 64 & 57 & $\begin{array}{l}2.24 \\
{[1.23]}\end{array}$ & 556 & 68 & 57 & $\begin{array}{l}5.91 \\
{[3.57]}\end{array}$ & 681 \\
\hline \multirow[t]{2}{*}{53 Retail } & $\begin{array}{l}533 \text { Food } \\
\text { and Drug } \\
\text { Retailers }\end{array}$ & 20 & 51 & $\begin{array}{l}2.25 \\
{[1.24]}\end{array}$ & 562 & 22 & 53 & $\begin{array}{l}6.41 \\
{[3.88]}\end{array}$ & 906 \\
\hline & $\begin{array}{l}537 \text { General } \\
\text { Retailers }\end{array}$ & 110 & 63 & $\begin{array}{l}2.28 \\
{[1.25]}\end{array}$ & 2220 & 121 & 68 & $\begin{array}{l}6.14 \\
{[3.71]}\end{array}$ & 3099 \\
\hline 55 Media & 555 Media & 130 & 65 & $\begin{array}{l}2.22 \\
{[1.22]}\end{array}$ & 1252 & 139 & 64 & $\begin{array}{l}5.73 \\
{[3.46]}\end{array}$ & 1375 \\
\hline $\begin{array}{l}57 \text { Travel } \\
\text { and Leisure }\end{array}$ & $\begin{array}{l}575 \text { Travel } \\
\text { and Leisure }\end{array}$ & 143 & 66 & $\begin{array}{l}2.20 \\
{[1.19]}\end{array}$ & 2462 & 149 & 69 & $\begin{array}{l}5.88 \\
{[3.55]}\end{array}$ & 2944 \\
\hline \multirow[t]{2}{*}{$\begin{array}{l}65 \text { Telecom- } \\
\text { munica- } \\
\text { tions }\end{array}$} & $\begin{array}{l}653 \text { Fixed } \\
\text { Line Tel- } \\
\text { ecommuni- } \\
\text { cations }\end{array}$ & 21 & 47 & $\begin{array}{l}2.14 \\
{[1.16]}\end{array}$ & 219 & 20 & 48 & $\begin{array}{l}6.07 \\
{[3.66]}\end{array}$ & 274 \\
\hline & $\begin{array}{l}657 \text { Mobile } \\
\text { Telecom- } \\
\text { munications }\end{array}$ & 11 & 37 & $\begin{array}{l}2.12 \\
\quad[1.14]\end{array}$ & 99 & 13 & 33 & $\begin{array}{l}5.82 \\
{[3.53]}\end{array}$ & 89 \\
\hline \multirow[t]{2}{*}{75 Utilities } & $\begin{array}{l}753 \text { Electric- } \\
\text { ity }\end{array}$ & 13 & 35 & $\begin{array}{l}2.16 \\
{[1.19]}\end{array}$ & 186 & 12 & 33 & $\begin{array}{l}6.08 \\
{[3.69]}\end{array}$ & 247 \\
\hline & $\begin{array}{l}757 \text { Gas, } \\
\text { Water, and } \\
\text { Multiutili- } \\
\text { ties }\end{array}$ & 19 & 35 & $\begin{array}{l}2.22 \\
{[1.24]}\end{array}$ & 365 & 17 & 35 & $\begin{array}{l}5.97 \\
{[3.60]}\end{array}$ & 419 \\
\hline 83 Banks & 835 Banks & 14 & 48 & $\begin{array}{l}2.23 \\
{[1.23]}\end{array}$ & 606 & 15 & 47 & $\begin{array}{l}6.32 \\
{[3.84]}\end{array}$ & 806 \\
\hline \multirow[t]{2}{*}{85 Insurance } & $\begin{array}{l}853 \text { Nonlife } \\
\text { Insurance }\end{array}$ & 47 & 43 & $\begin{array}{l}2.33 \\
{[1.33]}\end{array}$ & 701 & 47 & 46 & $\begin{array}{l}5.81 \\
{[3.50]}\end{array}$ & 703 \\
\hline & $\begin{array}{l}857 \text { Life } \\
\text { Insurance }\end{array}$ & 13 & 36 & $\begin{array}{l}2.24 \\
{[1.23]}\end{array}$ & 266 & 15 & 37 & $\begin{array}{l}6.01 \\
{[3.64]}\end{array}$ & 296 \\
\hline \multirow[t]{2}{*}{$\begin{array}{l}87 \text { Financial } \\
\text { Services }\end{array}$} & $\begin{array}{c}873 \text { Real } \\
\text { Estate }\end{array}$ & 85 & 47 & $\begin{array}{l}2.30 \\
{[1.30]}\end{array}$ & 827 & 85 & 50 & $\begin{array}{l}5.83 \\
{[3.50]}\end{array}$ & 875 \\
\hline & $\begin{array}{l}877 \text { General } \\
\text { Financial }\end{array}$ & 128 & 61 & $\begin{array}{l}2.25 \\
{[1.24]}\end{array}$ & 1346 & 130 & 64 & $\begin{array}{l}5.86 \\
{[3.53]}\end{array}$ & 1501 \\
\hline \multirow[t]{2}{*}{$\begin{array}{l}95 \text { Technol- } \\
\text { ogy }\end{array}$} & $\begin{array}{l}953 \text { Soft- } \\
\text { ware and } \\
\text { Computer } \\
\text { Services }\end{array}$ & 169 & 66 & $\begin{array}{l}2.19 \\
{[1.18]}\end{array}$ & 1356 & 189 & 69 & $\begin{array}{l}5.94 \\
{[3.59]}\end{array}$ & 1764 \\
\hline & $\begin{array}{c}957 \text { Technol- } \\
\text { ogy Hard- } \\
\text { ware and } \\
\text { Equipment }\end{array}$ & 42 & 54 & $\begin{array}{l}2.12 \\
\quad[1.13]\end{array}$ & 461 & 44 & 54 & $\begin{array}{l}6.10 \\
{[3.69]}\end{array}$ & 603 \\
\hline
\end{tabular}




\begin{tabular}{|c|c|c|c|c|c|c|c|c|c|}
\hline \multirow{2}{*}{$\begin{array}{l}\text { Two-digit } \\
\text { ICB codes }\end{array}$} & \multirow{2}{*}{$\begin{array}{l}\text { Three-digit } \\
\text { ICB codes }\end{array}$} & \multicolumn{4}{|c|}{ Upgrade portfolio } & \multicolumn{4}{|c|}{ Downgrade portfolio } \\
\hline & & $\begin{array}{l}\text { No. of } \\
\text { covered } \\
\text { firms }\end{array}$ & $\begin{array}{l}\text { No. of } \\
\text { broker- } \\
\text { age } \\
\text { houses }\end{array}$ & $\begin{array}{l}\text { Average } \\
\text { rating }\end{array}$ & $\begin{array}{l}\text { No. of } \\
\text { upward } \\
\text { revi- } \\
\text { sions }\end{array}$ & $\begin{array}{l}\text { No. of } \\
\text { covered } \\
\text { firms }\end{array}$ & $\begin{array}{l}\text { No. of } \\
\text { broker- } \\
\text { age } \\
\text { houses }\end{array}$ & $\begin{array}{l}\text { Average } \\
\text { rating }\end{array}$ & $\begin{array}{l}\text { No. of } \\
\text { down- } \\
\text { ward } \\
\text { revisions }\end{array}$ \\
\hline Overall & & 1958 & 111 & $\begin{array}{l}2.25 \\
\quad[1.24]\end{array}$ & 25,701 & 2081 & 109 & $\begin{array}{l}5.93 \\
{[3.58]}\end{array}$ & 30,374 \\
\hline
\end{tabular}

This appendix presents the distribution of 25,701 upward (30,374 downward) changes in analyst recommendations in the upgrade (downgrade) portfolio from January 1993 to June 2013 by industry sectors of the recommended firms, in terms of the number of firms covered, the number of brokerage houses, as well as the average rating and number of analyst recommendation revisions. All real-time analyst recommendations are obtained from Morningstar Company Intelligence. A rating of 1 reflects a strong buy, 2 a buy, 3 a weak buy, 4 a weak buy/hold, 5 a hold, 6 a hold/sell, 7 a weak sell, 8 a sell, and 9 a strong sell, which are reclassified into five categories: Strong Buy (1 and 2), Buy (3 and 4), Hold (5), Sell (6 and 7), and Strong Sell (8 and 9). An upgrade portfolio consists of all stocks with upward revisions to Strong buys or Buys from previous Strong Sells, Sells, or Holds, while a downgrade portfolio consists of all stocks with downward revisions to Strong Sells, Sells, or Holds from previous Strong Buys or Buys. We report the average rating for analyst recommendation revisions based on the nine-point rating scale, while in square brackets, we report the average rating based on the five-point rating scale

\section{Appendix 3: Time-series bootstrapping simulation method}

This appendix illustrates the rolling window-based time-series bootstrapping simulation method with the Fama and French (2015) five-factor model, but the application of the bootstrapping procedure to the CAPM, the Fama and French (1993) three-factor model, and the Carhart (1997) four-factor model is very similar, with the only modification of the following steps being the substitution of appropriate asset pricing models (see, Su and Zhang 2018).

First, in the first 1-year rolling window (January 3, 1995 to December 29, 1995), we estimate the Fama and French (2015) five-factor model to calculate the estimated alphas, factor loadings, and residuals using the time series of daily excess returns for the portfolio, $\left\{\left(R_{p, t}-R_{f, t}\right), t=T_{p, 1}, \ldots, T_{p, 252}\right\}$, where $T_{p, 1}$ and $T_{p, 252}$ are the first and last trading dates, respectively, in the rolling window:

$$
R_{p, t}-R_{f, t}=\hat{\alpha}_{p}+\hat{\beta}_{p}\left(R_{m, t}-R_{f, t}\right)+\hat{s}_{p} S M B_{t}+\hat{h}_{p} H M L_{t}+\hat{r}_{p} R M W_{t}+\hat{c}_{p} C M A_{t}+\hat{\varepsilon}_{p, t} .
$$

Second, we save the coefficient estimates, $\left\{\hat{\alpha}_{p}, \hat{\beta}_{p}, \hat{s}_{p}, \hat{h}_{p}, \hat{r}_{p}, \hat{c}_{p}\right\}$, the time series of estimated residuals, $\left\{\hat{\varepsilon}_{p, t}, t=T_{p, 1}, \ldots, T_{p, 252}\right\}$, and the $t$-statistic of alpha, $\hat{t}_{\hat{\alpha}_{p}}$.

Third, we generate a pseudo-time series of resampled residuals $\left\{\hat{\varepsilon}_{p, t_{b}}^{b}, t_{b}=T_{p, 1}^{b}, \ldots, T_{p, 252}^{b}\right\}$ by randomly drawing residuals from the saved residual vector $\left\{\hat{\varepsilon}_{p, t}\right\}$ with replacements, where $b$ is the bootstrapping simulation index. In the same way, we generate a pseudo-time series of risk factors $\left\{\left(R_{m, t_{b}}-R_{f, t_{b}}\right)^{b}, S M B_{t_{b}}^{b}, H M L_{t_{b}}^{b}, R M W_{t_{b}}^{b}, C M A_{t_{b}}^{b}\right\}$ by randomly drawing risk factors from the original risk factor vector $\left\{\left(R_{m, t}-R_{f, t}\right), S M B_{t}, H M L_{t}, R M W_{t}, C M A_{t}\right\}$ with replacements. 
Fourth, we generate a time series of pseudo-daily excess returns $\left(R_{p, t}-R_{f, t}\right)^{b}$ in the rolling window, imposing the null hypothesis of zero true performance $\left(\alpha_{p}=0\right)$ :

$$
\left\{\left(R_{p, t}-R_{f, t}\right)^{b}=0+\hat{\beta}_{p}\left(R_{m, t_{b}}-R_{f, t_{b}}\right)^{b}+\hat{s}_{p} S M B_{t_{b}}^{b}+\hat{h}_{p} H M L_{t_{b}}^{b}+\hat{r}_{p} R M W_{t_{b}}^{b}+\hat{c}_{p} C M A_{t_{b}}^{b}+\hat{\varepsilon}_{p, t_{b}}^{b}\right\}
$$

where $t=T_{p, 1}, \ldots, T_{p, 252} ; t_{b}=T_{p, 1}^{b}, \ldots, T_{p, 252}^{b}$.

Finally, we regress the pseudo-daily excess returns $\left(R_{p, t}-R_{f, t}\right)^{b}$ on the five factors:

$$
\left(R_{p, t}-R_{f, t}\right)^{b}=\hat{\alpha}_{p}^{b}+\hat{\beta}_{p}\left(R_{m, t}-R_{f, t}\right)+\hat{s}_{p} S M B_{t}+\hat{h}_{p} H M L_{t}+\hat{r}_{p} R M W_{t}+\hat{c}_{p} C M A_{t}+\hat{\varepsilon}_{p, t}
$$

The simulated $\hat{\alpha}_{p}^{b}$ represents the sampling variation around zero true performance, entirely due to random chance (luck). Repeating the above steps in each of the 4420 rolling windows from January 1996 to June 2013, we obtain a time series of simulated alphas, $\left\{\hat{\alpha}_{p}^{b}\right\}$, and their corresponding $t$-statistics, $\left\{\hat{t}_{\hat{\alpha}_{p}^{b}}\right\}$. We then order all simulated $\hat{\alpha}_{p}^{b}$ into a cumulative distribution function (CDF) of simulated $\hat{\alpha}_{p}^{b}$-a separate time series of luck distribution from the worst performing rolling window to the best performing rolling window, all of which are completely due to sell-side analysts' luck rather than their skill. We repeat the above bootstrapping simulation a large number of times, say, $b=1, \ldots, 5000$.

Note that our approach measures the performance distribution of the best performing rolling windows not just by resampling from distribution of the ex-post best performing rolling windows, but using the information about luck represented by all rolling windows. This is a major difference between our approach and those employed in prior studies, as they generally ignore the possibility that luck distribution encountered by all other performance distributions also provides highly valuable and relevant information (see, White 2000; Cuthbertson et al. 2008).

\section{References}

Altinkiliç O, Hansen RS (2009) On the information role of stock recommendation revisions. J Account Econ 48:17-36

Altinkiliç O, Balashov VS, Hansen RS (2013) Are analysts' forecasts informative to the general public? Manage Sci 59:2550-2565

Anderson A, Jones H, Martinez JV (2017) Measuring the added value of stock recommendations. Working paper, University of Oxford, Saïd Business School

Barber BM, Lehavy R, McNichols M, Trueman B (2001) Can investors profit from the prophets? Security analyst recommendations and stock returns. J Financ 56:531-563

Barber BM, Lehavy R, McNichols M, Trueman B (2003) Reassessing the returns to analysts' stock recommendations. Financ Anal J 59:88-96

Barber BM, Lehavy R, Trueman B (2007) Comparing the stock recommendation performance of investment banks and independent research firms. J Financ Econ 85:490-517

Barron OE, Byard D, Kile C, Riedl EJ (2002) High-technology intangibles and analysts' forecasts. J Account Res 40:289-312

Barth ME, Kasznik R, McNichols MF (2001) Analyst coverage and intangible assets. J Account Res 39:1-34

Boni L, Womack KL (2006) Analysts, industries, and price momentum. J Financ Quant Anal 41:85-109

Brookfield D, Su C, Bangassa K (2015) Investment style positioning of UK unit trusts. Eur J Financ 21:946-970

Brown R, Chan HWH, Ho CK (2009) Analysts' recommendations: from which signal does the market take its lead? Rev Quant Financ Account 33:91-111

Carhart MM (1997) On persistence in mutual fund performance. J Financ 52:57-82 
Colker S (1963) An analysis of security recommendations by brokerage houses. Q Rev Econ Bus 3:19-28

Cowles A (1933) Can stock market forecasters forecast? Econometrica 1:309-324

Cuthbertson K, Nitzsche D, O'Sullivan N (2008) UK mutual fund performance: skill or luck? J Empir Financ 15:613-634

Dimson E, Fraletti P (1986) Brokers' recommendations: the value of a telephone tip. Econ J 96:139-159

Ellis M, Thomas DC (2004) Momentum and the FTSE 350. J Asset Manage 5:25-36

Fama EF (1998) Market efficiency, long-term returns and behavioral finance. J Financ Econ 49:283-306

Fama EF, French KR (1993) Common risk factors in the returns on stocks and bonds. J Financ Econ 33:3-56

Fama EF, French KR (2010) Luck versus skill in the cross-section of mutual fund returns. J Financ 65:1915-1947

Fama EF, French KR (2015) A five-factor asset pricing model. J Financ Econ 116:1-22

Fang LH, Yasuda A (2014) Are stars' opinions worth more? The relation between analyst reputation and recommendation values. J Financ Serv Res 46:235-269

Green C (2006) The value of client access to analyst recommendations. J Financ Quant Anal 41:1-24

Gregory A, Tharyan R, Christidis A (2013) Constructing and testing alternative versions of the FamaFrench and Carhart models in the UK. J Bus Financ Account 40:172-214

Grossman SJ, Stiglitz JE (1980) On the impossibility of informationally efficient markets. Am Econ Rev 70:393-408

Groth JC, Lewellen WG, Schlarbaum GG, Lease RC (1979) An analysis of brokerage house securities recommendations. Financ Anal J 35:32-40

Gu F, Wang W (2005) Intangible assets, information complexity, and analysts' earnings forecasts. J Bus Financ Account 32:1673-1702

Hirshleifer D, Hsu P-H, Li D (2018) Innovative originality, profitability, and stock returns. Rev Financ Stud 31:2553-2605

Hobbs J, Kovacs T, Sharma V (2012) The investment value of the frequency of analyst recommendation changes for the ordinary investor. J Empir Financ 19:94-108

Hong H, Kubik JD (2003) Analyzing the analysts: career concerns and biased earnings forecasts. J Financ 58:313-351

Hong H, Stein JC (1999) A unified theory of underreaction, momentum trading, and overreaction in asset markets. J Financ 54:2143-2184

Hudson R, Dempsey M, Keasey K (1996) A note on the weak form efficiency of capital markets: the application of simple technical trading rules to UK stock prices - 1935 to 1994. J Bank Financ 20:1121-1132

Irvine PJ (2004) Analysts' forecasts and brokerage-firm trading. Account Rev 79:125-149

Ivkovic Z, Jegadeesh N (2004) The timing and value of forecast and recommendation revisions. J Financ Econ 73:433-463

Jackson AR (2005) Trade generation, reputation, and sell-side analysts. J Financ 60:673-717

Jegadeesh N, Kim W (2006) Value of analyst recommendations: international evidence. J Financ Mark 9:274-309

Jegadeesh N, Kim W (2010) Do analysts herd? An analysis of recommendations and market reactions. Rev Financ Stud 23:901-937

Jegadeesh N, Kim J, Krische SD, Lee CMC (2004) Analyzing the analysts: when do recommendations add value? J Financ 59:1083-1124

Keim DB, Madhavan A (1998) The cost of institutional equity trades. Financ Anal J 54:50-69

Kucheev YO, Ruiz F, Sorensson T (2017) Do stars shine? Comparing the performance persistence of star sell-side analysts listed by institutional investor, the Wall Street Journal, and StarMine. J Financ Serv Res 52:277-305

Kwon SS (2002) Financial analysts' forecast accuracy and dispersion: high-tech versus low-tech stocks. Rev Quant Financ Acc 19:65-91

Li X, Brooks C, Miffre J (2009) Low-cost momentum strategies. J Asset. Manage 9:366-379

Ljungqvist A, Malloy C, Marston F (2009) Rewriting history. J Financ 64:1935-1960

Logue DE, Tuttle DL (1973) Brokerage house investment advice. Financ Rev 8:38-54

Lyon JD, Barber BM, Tsai C-L (1999) Improved methods for tests of long-run abnormal stock returns. J Financ 54:165-201

Markowitz TJ, Grinblatt M (1999) Do industries explain momentum? J Financ 54:1249-1290

Mehran H, Stulz RM (2007) The economics of conflicts of interest in financial institutions. J Financ Econ 85:267-296 
Mikhail MB, Walther BR, Willis RH (2004) Do security analysts exhibit persistent differences in stock picking ability? J Financ Econ 74:67-91

Nolte I, Nolte S, Vasios M (2014) Sell-side analysts' career concerns during banking stresses. J Bank Financ 49:424-441

Novy-Marx R, Velikov M (2016) A taxonomy of anomalies and their trading costs. Rev Financ Stud 29:104-147

Rees L, Sharp NY, Wong PA (2017) Working on the weekend: do analysts strategically time the release of their recommendation revisions? J Corp Financ 45:104-121

Ryan P, Taffler RJ (2006) Do brokerage houses add value? The market impact of UK sell-side analyst recommendation changes. Brit Account Rev 38:371-386

Stickel SE (1995) The anatomy of the performance of buy and sell recommendations. Financ Anal J $51: 25-39$

Su C, Zhang H (2018) A time-series bootstrapping simulation method to distinguish sell-side analysts' skill from luck. Working paper, Newcastle University Business School

Sun J (2011) The effect of analyst coverage on the informativeness of income smoothing the international. Int J Account 46:333-349

Timmermann A, Granger CWJ (2004) Efficient market hypothesis and forecasting. Int J Forecasting 20:15-27

White H (2000) A reality check for data snooping. Econometrica 68:1097-1126

Womack KL (1996) Do brokerage analysts' recommendations have investment value? J Financ 51:137-167 